\title{
STAT1 deficiency supports PD-1/PD-L1 signaling resulting in dysfunctional TNFa mediated immune responses in a model of NSCLC
}

\author{
Juliane Friedrich ${ }^{1}$, Lisanne Heim ${ }^{1}$, Denis I. Trufa ${ }^{2}$, Horia Sirbu ${ }^{2}$, Ralf J. Rieker ${ }^{3}$, \\ Mircea T. Chiriac ${ }^{4}$ and Susetta Finotto ${ }^{1}$ \\ ${ }^{1}$ Department of Molecular Pneumology, Friedrich Alexander University Erlangen-Nürnberg, Erlangen, Germany \\ ${ }^{2}$ Department of Thoracic Surgery, Friedrich Alexander University Erlangen-Nürnberg, Erlangen, Germany \\ ${ }^{3}$ Institute of Pathology, Friedrich Alexander University Erlangen-Nürnberg, Erlangen, Germany \\ ${ }^{4}$ Department of Medicine 1-Gastroenterology, Pneumology and Endocrinology, Friedrich Alexander University Erlangen- \\ Nürnberg, Erlangen, Germany
}

Correspondence to: Susetta Finotto, email: Susetta.Neurath-Finotto@uk-erlangen.de

Keywords: NSCLC, STATI, PDL1

Received: September 30, $2018 \quad$ Accepted: November 26, $2018 \quad$ Published: December 14, 2018

Copyright: Friedrich et al. This is an open-access article distributed under the terms of the Creative Commons Attribution License 3.0 (CC BY 3.0), which permits unrestricted use, distribution, and reproduction in any medium, provided the original author and source are credited.

\section{ABSTRACT}

In this study we described that Signal Transducer and Activator of Transcription 1 (STAT1) is a key point regulator of PD-1 in tumour infiltrating lymphocytes and PD-L1 in Tumour associated macrophages (TAM) in NSCLC. In our murine model of adenocarcinoma targeted deletion of Stat1 was found associated with enhanced tumour growth, impaired differentiation into M1-like macrophages from the bone marrow, the accumulation of tumor associated macrophages overexpressing PDL1 and impaired $\mathrm{T}$ cell responses in the tumor microenvironment by affecting TNFa responses.

In our human NSCLC patient cohort we found that loss of isoforms STAT1 $a$ and STAT1 $\beta$ mRNA in the tumoural region of the lung correlates with increased tumor size in NSCLC patients. Therefore, STAT1 isoform regulation could be considered for future therapeutical strategies associated to current immune-checkpoint blockade therapy in NSCLC.

\section{INTRODUCTION}

The Programmed cell death 1 ligand 1, inhibitory ligand $\mathrm{PD}-\mathrm{L} 1$, the ligand for the $\mathrm{T}$ cell inhibitory receptor PD-1, is a key mediator in regulating anti-tumor responses in human cancer patients as well as in different murine cancer disease model [1]. PD-L1 is expressed by various cancer cells in response to inflammatory cytokines [2]. Previous reports showed that PD-L1 is also expressed on tumor infiltrating macrophages (TAM) which is further on associated with a poor outcome of NSCLC patients [3]. Macrophages are important mediators in tumor defense by directly eliminating tumor cells [4] by secreting the reactive nitrogen species nitric oxide and TNF $\alpha$. TNF $\alpha$ is a pleiotropic cytokine, which plays a dual role in the tumor microenvironment by controlling various functions such as apoptosis, invasion and proliferation [5]. In melanoma patients an increased TNF gene expression is seems to be linked to $\alpha \mathrm{PD}-1$ therapy [6]. Emerging immunotherapy strategies that block PD-1 or PD-L1 [7-9] have radically changed the fight against cancer. However, two third of the patients do not respond to $\alpha \mathrm{PD}-1$ therapy and in a significant proportion of patients treated with immunecheckpoint blockade (ICB) antibodies show relapse within 
two years after treatment induction [10-12]. Moreover, it has been reported that patients with tumors that express the PD-1 ligand prior to the treatment have a higher chance to respond to the treatment strategy [13] especially in the case of patients that suffered from NSCLC $[14,15]$. Our group has previously defined STAT1 as an important key regulator in NSCLC, since we found a decreased activation of STAT1 in the tumoural region of patients that suffered from NSCLC compared to the tumor free control region [16]. STAT1 is described to play a key role in tumorigenesis by controlling a large variety of functions such as activating certain genes that block cell cycle progression or inhibiting angiogenesis [17]. Other groups have recently reported that JAK-STAT-mediated chronic inflammation impairs cytotoxic $\mathrm{T}$ lymphocyte activation to decrease anti-PD-1 immunotherapy efficacy in pancreatic cancer [18].

Here we directly evaluate the relative role of host STAT1 expression in immune cells and the PD-1/ PD-L1 signaling axis in a murine model of lung adenocarcinoma. Loss of STAT1 in the host was found associated with increased tumour load, inhibition of the anti-tumour immune responses and by the upregulation of the immune suppressive markers PD-1 in TIL and PD-L1 in TAM as well as dysfunctional TNF $\alpha$ immune responses.

\section{RESULTS}

\section{PD-1 blockade resulted in tendencial increased expression of Stat1 $m R N A$}

Murine lung tumor development was induced by intravenously injection of LL/2-luc-M38 cells into the tail vein. At described days mice were treated intraperitoneally with $150 \mu \mathrm{g} \alpha \mathrm{PD}-1$ antibody or related isotype control (Supplementary Figure 1A). Similar to the previous described findings in humans [10-12] only half of the lung tumor bearing mice responded to the PD-1 blockade treatment [19]. Successful in vivo blockade of PD-1 was found associated with a tendencial upregulation of Stat1 (Supplementary Figure 1B) and Tbet (Supplementary Figure 1C) mRNA expression measured in total lung cells derived from tumor bearing mice compared to tumor bearing mice treated with the related isotype control. Since no difference in the tumor development was detected, total lung cells from tumor bearing mice treated with blocking antibody or related isotype control were in vitro rechallenged for $24 \mathrm{~h}$ with $10 \mu \mathrm{g} \alpha \mathrm{PD}-1$ antibody or IgG2a, followed by qPCR analysis (Supplementary Figure 1D). In vivo blockade of $\mathrm{PD}-1$ dominated the in vitro re-challenge. Stat1, STAT2, STAT3 (Supplementary Figure 1E-1G) and Thet mRNA expression (Supplementary Figure 1H) were tendencially upregulated in total lungs cells derived from $\alpha$ PD-1 antibody- treated tumor bearing mice independent from in vitro re-challenge.

\section{Loss of isoforms STAT1 $\alpha$ and STAT1 $\beta$ mRNA in the tumoural region of the lung correlates with increased tumor size in NSCLC patients}

We next wanted to determine if STAT1 is linked to tumor development in NSCLC patients. Our cohorts of patients recently described [16] include Adenocarcinoma (ADC) and Squamous cell carcinoma patients (SCC), collectively grouped as NSCLC patients (Table 1). For our studies we perform protein and mRNA analysis from tissue samples derived from the tumor itself (solid tumor, TU), the peritumoural area (PT, $2 \mathrm{~cm}$ away from the tumor) and a tumor free control region (CTR, at least $5 \mathrm{~cm}$ away from the tumor) (Figure 1A). STAT1 can be differentiated in STAT $1 \alpha$, the predominantly active proapoptotic form and STAT1 $\beta$, which is able to modulate the effects of STAT $1 \alpha[20,21]$. In our previous work we reported decreased phosphorylation, activation, of the STAT $1 \alpha$ but not STAT1 $\beta$ isoform at protein level, in the tumoural region of the lung of our cohort of patients with ADC [21]. In the present study, we correlated both STAT1 mRNA isoforms, expressed in the CTR, PT and TU region with the tumor size. Upregulated STAT1 $\alpha$ mRNA was found associated with smaller tumor size in the TU region, whereas no correlation was found for STAT1 $\alpha$ in the PT and CTR region from patients that suffered from NSCLC. Notably, upregulation of the STAT1 $\beta$ isoform correlated with reduced tumor size in all three regions of patients that suffered from NSCLC (Figure 1B). We next asked, whether reduced STAT1 mRNA expression and big tumor size is linked to dysfunctional STAT1 activation. Therefore, the activated form of STAT1 (pSTAT1) was measured via Western Blot analysis. Indeed, we found reduced pSTAT1 in the TU compared to the CTR region in patients that suffered from NSCLC. In the same protein samples, PD-L1 protein expression was found upregulated in the TU region compared to the CTR region (Figure $1 \mathrm{C}$ ). We next analysed $P D L 1 \mathrm{mRNA}$ expression in a bigger cohort of patients. Here we found that increased PDL1 mRNA expression in the group of NSCLC patients with more severe tumor grade (Figure 1D).

\section{In vivo blockade of PD-L1 is associated with upregulation of PD-1 in tumor infiltrating lymphocytes (TIL) in a murine model of lung adenocarcinoma}

As it has been reported that PD-L1 expression in tumor patients is linked to a better response to immunotherapy [13] and we found upregulated PDL1 expression in the TU region of our patient cohort, we next examined the effect of in vivo PD-L1 blockade in our murine model of lung cancer. Mice were intraperitoneally treated with $\alpha \mathrm{PD}-\mathrm{L} 1$ antibody or IgG2b isotype control at described days and tumor development was measured via 
Table 1: Clinical parameters of patients that suffered from lung adenocarcinoma

\begin{tabular}{|c|c|c|c|c|c|c|c|c|c|c|}
\hline Sample ID & $\begin{array}{c}\text { Histological } \\
\text { Classification }\end{array}$ & $\begin{array}{c}\text { Maximal tumor } \\
\text { diameter }[\mathrm{cm}]\end{array}$ & Grading & $\mathbf{T}$ & $\mathbf{N}$ & M & TNM Stadium & Gender & Age & Average Smoking $(\mathrm{P} / \mathrm{Y})$ \\
\hline 1-MP & SCC & 1,3 & G3 & $1 \mathrm{~b}$ & 0 & 0 & IA & Male & 80 & 40 \\
\hline 2-MP & $\mathrm{SCC}$ & 5,1 & G3 & $1 \mathrm{a}$ & 0 & 0 & IA & Male & 57 & 40 \\
\hline 3-MP & $\mathrm{ADC}$ & 5 & G3 & $2 \mathrm{a}$ & 0 & 0 & IB & Male & 79 & 60 \\
\hline 4-MP & $\mathrm{SCC}$ & 2 & G3 & $1 b$ & 1 & 0 & IIA & Female & 53 & 25 \\
\hline 5-MP & $\mathrm{SCC}$ & 10,5 & G2 & 3 & 0 & 0 & IIB & Female & 67 & 50 \\
\hline 8-MP & $\mathrm{SCC}$ & 5,5 & G3 & 3 & 0 & 0 & IIB & Male & 66 & 30 \\
\hline 9-MP & $\mathrm{ADC}$ & 2,7 & $\mathrm{G} 2$ & $1 b$ & 2 & 0 & IIIA & Female & 84 & 0 \\
\hline 13-MP & $\mathrm{SCC}$ & 3 & G3 & $1 b$ & 0 & 0 & IA & Male & 69 & 50 \\
\hline 14-MP & SCC & 1,9 & G2 & $1 \mathrm{a}$ & 0 & 0 & IA & Female & 58 & 30 \\
\hline 15-MP & $\mathrm{ADC}$ & 2,5 & G3 & $1 b$ & 0 & 0 & IA & Male & 63 & 100 \\
\hline 16-MP & $\mathrm{ADC}$ & 4,6 & G3 & 3 & 0 & 0 & IIB & Female & 70 & 15 \\
\hline 17-MP & $\mathrm{ADC}$ & 2,6 & G2 & 2 & 0 & 0 & IB & Male & 74 & 70 \\
\hline 19-MP & $\mathrm{ADC}$ & 6,5 & \# & $2 b$ & 0 & 0 & IIA & Female & 55 & 30 \\
\hline 21-MP & SCC & 2,5 & G1 & $1 b$ & 0 & 0 & IA & Male & 41 & 10 \\
\hline 22-MP & $\mathrm{ADC}$ & 7 & G3 & $2 b$ & 1 & 0 & IIB & Male & 68 & 82 \\
\hline 23-MP & $\mathrm{ADC}$ & 4,5 & G2 & $2 \mathrm{a}$ & 0 & 0 & IB & Male & 73 & 75 \\
\hline 26-MP & $\mathrm{ADC}$ & 1,3 & G3 & $1 \mathrm{a}$ & 0 & 1 & IV & Female & 52 & 50 \\
\hline 27-MP & $\mathrm{ADC}$ & 1,4 & G3 & $1 \mathrm{a}$ & 0 & 0 & IA & Female & 70 & 50 \\
\hline 28-MP & $\mathrm{ADC}$ & 1,2 & G3 & $1 \mathrm{a}$ & 0 & 0 & IA & Male & 76 & 60 \\
\hline 29-MP & SCC & 3,7 & G3 & $1 b$ & 0 & 0 & IIB & Male & 74 & 100 \\
\hline 30-MP & SCC & 1,8 & G3 & $1 \mathrm{a}$ & 0 & 0 & IA & Female & 70 & 30 \\
\hline 32-MP & $\mathrm{ADC}$ & 4,4 & G3 & $2 \mathrm{a}$ & 2 & 0 & IIIA & Female & 60 & 30 \\
\hline 34-MP & $\mathrm{ADC}$ & 1,8 & G3 & 1 & 0 & 0 & IA & Female & 51 & 45 \\
\hline 35-MP & $\mathrm{ADC}$ & 3 & G3 & $1 b$ & 0 & 0 & IA & Female & 72 & 0 \\
\hline 36-MP & SCC & 3,5 & G3 & $2 a$ & 1 & 0 & IB & Male & 74 & 40 \\
\hline 37-MP & SCC & 3,3 & G2 & $2 \mathrm{a}$ & 1 & 0 & IIA & Male & 60 & 45 \\
\hline 41-MP & SCC & 1,3 & G3 & 3 & 1 & 0 & IIIA & Male & 70 & 42 \\
\hline 42-MP & SCC & 1,5 & G3 & $2 b$ & 1 & 0 & IIB & Male & 74 & 40 \\
\hline 40-MP & $\mathrm{ADC}$ & 1,8 & G3 & $1 \mathrm{a}$ & 1 & 0 & IIA & Male & 82 & 100 \\
\hline 43-MP & $\mathrm{ADC}$ & 4 & G3 & $2 \mathrm{a}$ & 2 & 0 & IIIA & Female & 72 & 0 \\
\hline 46-MP & SCC & 9,5 & G3 & 3 & 1 & 0 & IIIA & Male & 60 & 30 \\
\hline 47-MP & SCC & 6 & G3 & $2 b$ & 0 & 0 & IIA & Male & 64 & 80 \\
\hline 48-MP & SCC & 5 & G2 & $2 b$ & 0 & 0 & IIA & Male & 55 & 20 \\
\hline 50-MP & SCC & 2,5 & G3 & 3 & 1 & 0 & IIIA & Male & 70 & 0 \\
\hline 51-MP & $\mathrm{ADC}$ & 2,4 & G3 & $1 \mathrm{~b}$ & 2 & 1 & IV & Male & 62 & 90 \\
\hline 53-MP & $\mathrm{ADC}$ & 2,25 & G2 & $1 \mathrm{a}$ & 0 & 0 & IA & Male & 62 & 10 \\
\hline 54-MP & SCC & 4,1 & G2 & 3 & 0 & 0 & IIB & Male & 72 & 0 \\
\hline 55-MP & $\mathrm{ADC}$ & 1,8 & G3 & $1 \mathrm{a}$ & 2 & 0 & IIIA & Female & 64 & 40 \\
\hline 56-MP & $\mathrm{ADC}$ & 4 & G2 & $2 \mathrm{a}$ & 0 & 0 & IB & Female & 67 & 0 \\
\hline 57-MP & $\mathrm{ADC}$ & 3,8 & G2 & $2 \mathrm{a}$ & 0 & 0 & IB & Female & 35 & 10 \\
\hline 58-MP & $\mathrm{ADC}$ & 6,5 & G3 & 3 & 0 & 0 & IIB & Female & 69 & 0 \\
\hline 59-MP & $\mathrm{ADC}$ & 0,9 & G2 & 4 & 0 & 0 & IIIA & Male & 70 & \# \\
\hline 60-MP & SCC & 2,5 & G2 & $1 b$ & 1 & 0 & IIA & Male & 71 & \# \\
\hline 61-MP & SCC & 1,1 & G2 & $1 \mathrm{a}$ & 0 & 0 & IA & Male & 75 & $\#$ \\
\hline 62-MP & $\mathrm{ADC}$ & 3,5 & G2 & $1 b$ & 0 & 0 & IA & Female & 80 & \# \\
\hline 62-MP & $\mathrm{ADC}$ & 3,5 & G2 & $1 b$ & 0 & 0 & IA & Female & 80 & $\#$ \\
\hline 63-MP & SCC & 9 & G3 & 3 & 1 & 0 & IIIA & Male & 69 & $\#$ \\
\hline 64-MP & $\mathrm{ADC}$ & 3,5 & G2 & $1 b$ & 0 & 0 & IA & Male & 55 & 35 \\
\hline 65-MP & SCC & 2,8 & G3 & $1 \mathrm{~b}$ & 0 & 0 & IA & Female & 76 & \# \\
\hline
\end{tabular}

Abbreviations: $\mathrm{ADC}=$ Adenocarcinoma, $\mathrm{SCC}=$ Squamous Cell Carcinoma, $\mathrm{G} 2=$ moderately differentiated; G3=poorly differentiated, T-primary tumor: $0=$ no evidence of primary tumor; $1 \mathrm{a}=$ tumor $2 \mathrm{~cm}$ or less in greatest dimension; $1 \mathrm{~b}=$ tumor more than $2 \mathrm{~cm}$ but not more than $3 \mathrm{~cm}$ in greatest dimension; $2 \mathrm{a}=$ tumor more than $3 \mathrm{~cm}$ but not more than $5 \mathrm{~cm}$ in greatest dimension; $2 \mathrm{~b}=$ tumor more than $5 \mathrm{~cm}$ but not more than $7 \mathrm{~cm}$ in greatest dimension; $3=$ tumor more than $7 \mathrm{~cm}$. N-regional lymph nodes: $0=$ no regional lymph node metastasis; $1=$ metastasis in ipsilateral peribronchial and/or ipsilateral hilar lymph nodes and intrapulmonary nodes, including involvement by direct extension; $2=$ Metastasis in ipsilateral mediastinal and/or subcarinal lymph node(s). M-distant metastasis: $0=$ no distant metastasis; $1=$ distant metastasis, \# means not specified. 
in vivo bioluminescence (Figure 2A, 2C). Tumor bearing mice in vivo treated with $\alpha \mathrm{PD}-\mathrm{L} 1$ antibodies show a better survival outcome compared to tumor bearing mice in vivo treated with the IgG2b isotype control (Figure $2 \mathrm{~B}$ ). Despite the better survival rate, we could neither detect an altered tumor development in both groups (Figure 2C) nor a change in weight loss during the tumor development (Supplementary Figure 2A). To evaluate whether in vivo blockade of PD-L1 was successful, we analysed PD-L1 expression on total lung cells derived from tumor bearing mice. PD-L1 expression was successfully reduced during in vivo blockade on $\mathrm{CD}_{11} \mathrm{~b}^{+}$cells (Figure $2 \mathrm{D}$ ) as well as on total cells (Supplementary Figure 2B) and on epithelial cells, characterized as $\mathrm{EpCAM}^{+}$cells (Supplementary
Figure 2C). Since PD-1 is the binding partner to PD-L1 [22], we next analysed the expression of PD-1 on tumor infiltrating cells. Notably, we found an upregulation of PD-1 on $\mathrm{CD}^{+}$lung tumor infiltrating T cells (Figure 2E) as well as on $\mathrm{CD}^{+}$lung tumor infiltrating $\mathrm{T}$ cells in mice in vivo treated with $\alpha \mathrm{PD}-\mathrm{L} 1$ antibody compared to isotype control IgG2b (Figure 2F).

\section{Targeted deletion of host STAT1 results in induced lung tumor development}

Since responders to in vivo blockade of PD-1 show a trend to upregulation of Stat1 expression in total lung cells, we next examined the role of STAT1 during lung

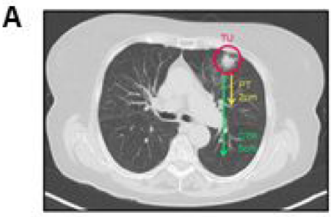

B
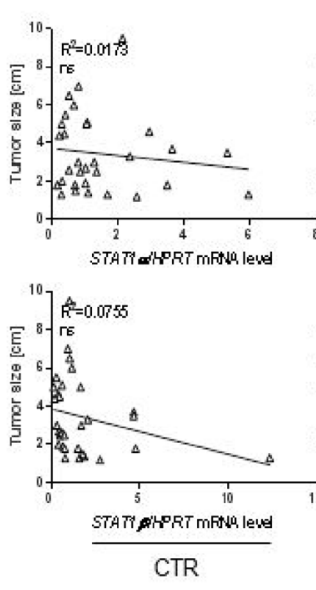

D

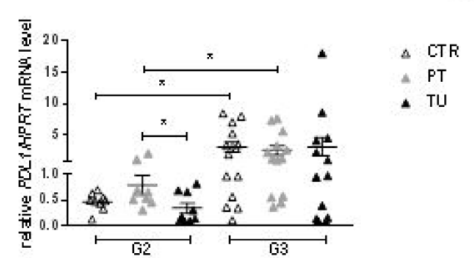

C
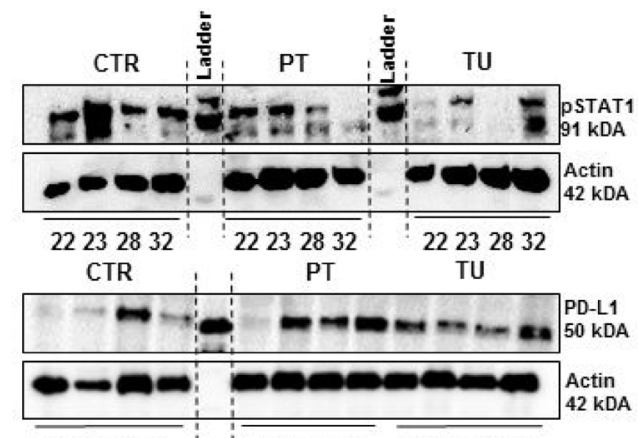

$\overline{22232832}: \overline{22232832} \overline{22232832}$
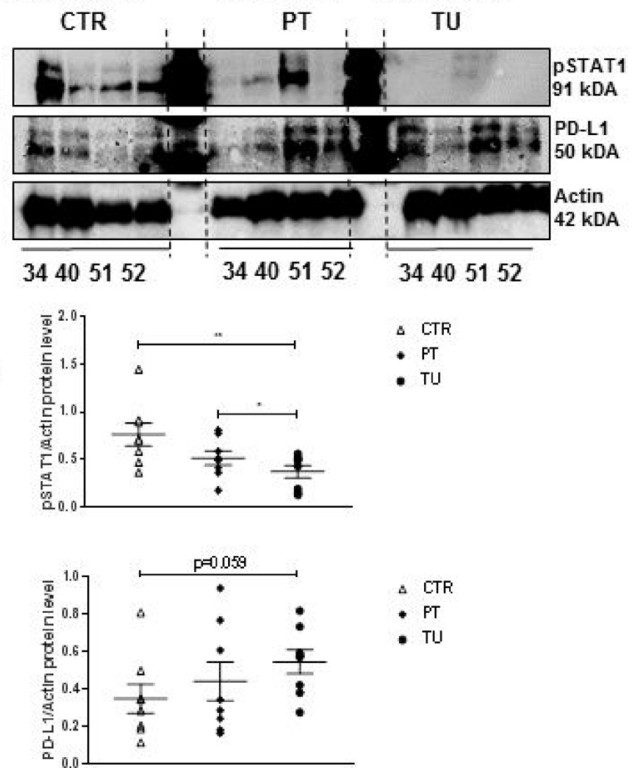

$\triangle$ CTR

- PT

- TU

$\triangle$ CTR

* PT

- TU

Figure 1: Dysfunction of STAT1 in patients that suffered from NSCLC and upregulation of the oncogene PD-L1. (A) Definition of analyzed tissue samples derived from patients that suffered from NSCLC. Tumoural region (TU), the solid tumor; peritumoural region (PT), tissue samples $2-3 \mathrm{~cm}$ away from the solid tumor; control region (CTR), tumor free region, at least $5 \mathrm{~cm}$ away from the solid tumor. (B) Decreased STAT1 $\alpha$ mRNA, measured in the TU region of patients that suffered from NSCLC is associated with enlarged tumor size. No correlation between STAT1 $\alpha$ mRNA level and tumor size were detected in the CTR and PT region. Impaired expression level of STAT1 $\beta$ mRNA is associated with enlarged tumor size in the CTR, PT and TU region of patients that suffered from $\operatorname{NSCLC~}\left(\mathrm{n}_{\mathrm{CTR}}=31, \mathrm{n}_{\mathrm{PT}}=24, \mathrm{n}_{\mathrm{TU}}=30\right)$. (C) In the tumoural microenvironment a significantly reduced activation of STAT1 (pSTAT1) was detectable on protein level. Impaired activation of pSTAT1 is associated with a slightly increase on PD-L1 on protein level in the tumoural region of patients that suffered from $\mathrm{ADC}\left(\mathrm{n}_{\mathrm{CTR}}=8, \mathrm{n}_{\mathrm{PT}}=8, \mathrm{n}_{\mathrm{TU}}=8\right)$. (D) Upregulated PDL1 mRNA in patients that suffered from NSCLC is associated with advanced tumor stage from G2 to $\mathrm{G} 3\left(\mathrm{n}_{\mathrm{CTR} \mathrm{G} 2}=9 ; \mathrm{n}_{\mathrm{PTG} 2}=9 ; \mathrm{n}_{\mathrm{TU} \mathrm{G} 2}=9 ; \mathrm{n}_{\mathrm{CTR} \mathrm{G} 3}=14 ; \mathrm{n}_{\mathrm{PT} \mathrm{G} 3}=13 ; \mathrm{n}_{\mathrm{TU} \mathrm{G} 3}=13\right)$. Data are presented as mean values $\pm \mathrm{SEM}$; unpaired $t$-test ${ }^{*} p<0.05,{ }^{* * *} p<0.01,{ }^{* * *} p<0.001$. 
adenocarcinoma development. To induce lung tumor development B16/C57j mice were injected with LL/2luc-M38 cells intravenously, tumor load was measured at described days via in vivo bioluminescence (Figure $3 \mathrm{~A}-3 \mathrm{C}$ ). Total cells from tumor bearing lungs from B16/ $\mathrm{C} 57 \mathrm{j}$ mice were isolated at day 13 and 17 after tumor induction. Stat 1 mRNA level decreased with progressed lung tumor development in total lung cells derived from tumor bearing mice (Figure 3B). Because of this finding, we next examined the total deletion of host STAT1 on lung tumor development. Therefore, we used STAT1 knockout (KO) mice in our murine model of lung adenocarcinoma. STAT1 KO mice show a rapid and significantly severe lung tumor development compared to tumor bearing B16/ C67j mice (Figure 3C). Hematoxylin and Eosin (H\&E) staining verified findings of in vivo bioluminescence and showed an increased tumor infiltrated area in lungs of STAT1 KO mice compared to B16/C57j mice (Figure 3D). Bronchoalveolar lavage fluid (BALF) was taken at the end of experiment. Total cell count in the BALF was not altered between tumor bearing STAT1 KO mice and B16/C57j mice. However, cells in the BALF were predominantly characterized as macrophages via MayGrünwald-Giemsa staining in STAT1 KO mice, whereas in tumor bearing B16/C56j wild type mice predominantly bronchial ciliated epithelial cells were found (Figure 3E).

\section{Loss of STAT1 impairs differentiation into M1- like macrophages}

Since we found a strong accumulation of PD-L1 ${ }^{+}$ macrophages in the BALF of tumor bearing STAT1 KO mice, we next wanted to examine the effect of STAT1 on the differentiation of macrophages. Macrophages derived
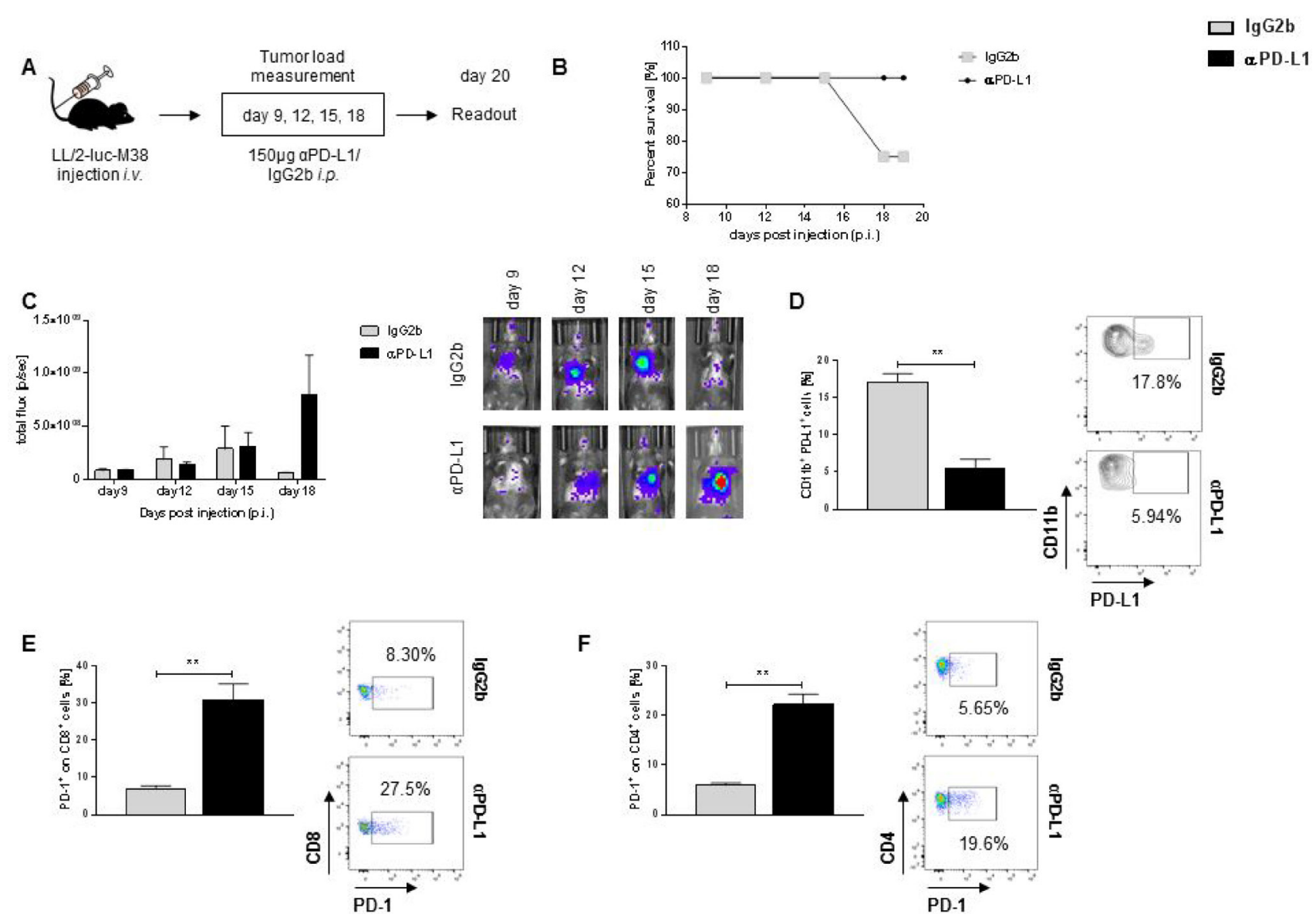

Figure 2: $\alpha$ PD-L1 antibody therapy resulted in better survival rates but is also associated with increase expression of PD-1 in TIL. (A) Experimental design. Mice were injected i.v. with $1 \times 10^{6} \mathrm{LL} / 2$-luc-M38 cells. Starting at day 9 post injection, every three days mice were treated i.p. with $150 \mu \mathrm{g} \alpha \mathrm{PD}-\mathrm{L} 1$ or related isotype control IgG2b. Lung tumor development was detected via bioluminescence. (B) $\alpha$ PD-L1 antibody treatment of naive tumor bearing mice resulted in a better survival rate compared to tumor bearing mice treated with related isotype control IgG2b $\left(\mathrm{n}_{\mathrm{IgG} 2 \mathrm{~b}}=4 ; \mathrm{n}_{\mathrm{\alpha PD}-\mathrm{L} 1}=4\right)$. (C) $\alpha \mathrm{PD}-\mathrm{L} 1$ antibody treatment did not resulted in an altered lung tumor development compared to mice treated with IgG2b $\left(\mathrm{n}_{\mathrm{IgG} 2 \mathrm{~b}}=4 ; \mathrm{n}_{\alpha \mathrm{PD}-\mathrm{L} 1}=4\right)$. (D) $\alpha \mathrm{PD}-\mathrm{L} 1$ antibody treatment successfully inhibited the PD-L1 expression on $\mathrm{CD}_{11 \mathrm{~b}^{+}}$tumor infiltrating cells $\left(\mathrm{n}_{\mathrm{lgG} 2 \mathrm{~b}}=3 ; \mathrm{n}_{\mathrm{aPD}-\mathrm{Ll}}=4\right)$. (E) Blockade of PD-L1 is associated with an increased infiltration of PD- $1^{+} \mathrm{CD} 8^{+}$ $\mathrm{T}$ cells in the lungs of tumor bearing mice compared to tumor bearing mice treated with $\operatorname{IgG} 2 \mathrm{~b}\left(\mathrm{n}_{\mathrm{IgG} 2 \mathrm{~b}}=3 ; \mathrm{n}_{\alpha \mathrm{PD}-\mathrm{L} 1}=4\right)$. (F) $\alpha \mathrm{PD}-\mathrm{L} 1$ treatment resulted in a significantly enhanced accumulation of $\mathrm{PD}-1^{+} \mathrm{T} \mathrm{CD} 4^{+}$cells in the lungs of tumor bearing compared to mice treated with related isotype control $\operatorname{IgG} 2 \mathrm{~b}\left(\mathrm{n}_{\mathrm{IgG} 2 \mathrm{~b}}=3 ; \mathrm{n}_{\mathrm{aPD}-\mathrm{L} 1}=4\right)$. Data are presented as mean values $\pm \mathrm{SEM}$; unpaired $t$-test ${ }^{*} p<0.05,{ }^{* *} p<0.01,{ }^{* * *} p<0.001$. 
from the bone marrow are recruited into different tissues to react to different cytokines or immune stimuli [23] therefore we analysed bone marrow derived macrophages from naïve STAT1 KO mice in order to investigate the effect of STAT1 on differentiation of macrophages. Bone marrow cells were isolated from fibula and tibia. Cells were cultured with GM-CSF for ten days and differentiated into M1-like macrophages with the respective cytokine mixture for $48 \mathrm{~h}$ (Supplementary Figure 3A). Naïve bone marrow derived M1 macrophages differentiated from STAT1 KO mice show a strong defect in Nos 2 mRNA expression (Supplementary Figure 3B). Supernatants collected after differentiation into M1 macrophages have lower levels of soluble TNF $\alpha$ compared to M1-like macrophages derived from B16/
C57j mice (Supplementary Figure 3C). Interestingly, we found significantly upregulated mRNA expression of $P d 1$ in Stat1 deficient M1 macrophages compared to wildtype M1 macrophages (Supplementary Figure 3D). As macrophages are able to directly eliminate tumor cells [4] by secreting inflammatory cytokines, we next evaluated the ability of Stat1 deficient M1 macrophages to kill LL/2-luc-M38 lung adenocarcinoma cells used to induce lung tumor in mice. For this assay LL/2-luc-M38 were seeded and incubated with supernatants collected from M1 differentiated macrophages diluted in DMEM medium (conditioned medium $=\mathrm{CM}$ ). After $24 \mathrm{~h}$ incubation with $\mathrm{CM}$, cell viability was measured via bioluminescence (Supplementary Figure 3E). LL/2-luc-M38 cultured with $20 \%$ or $50 \%$ of CM from STAT1-/- mice showed
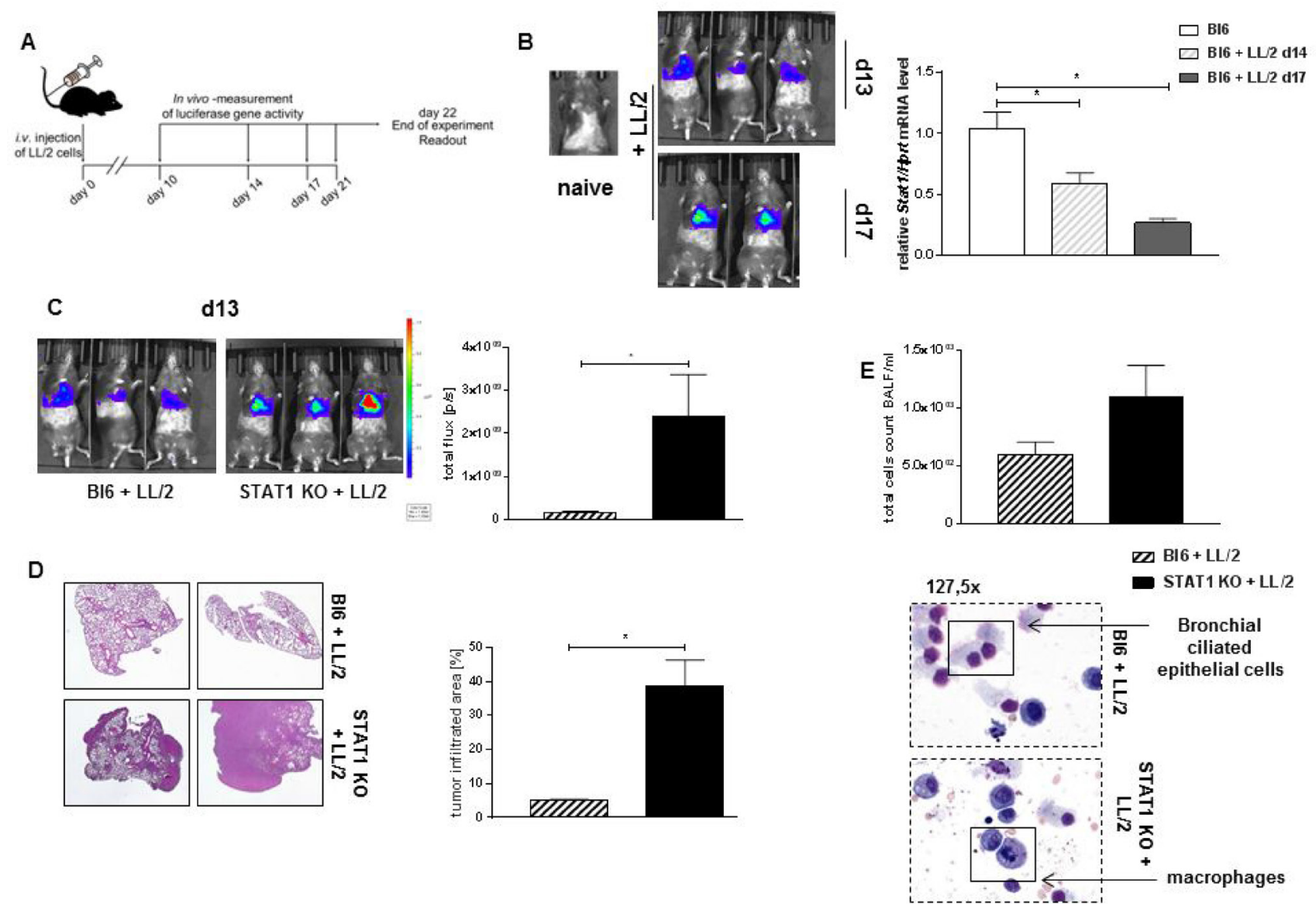

D
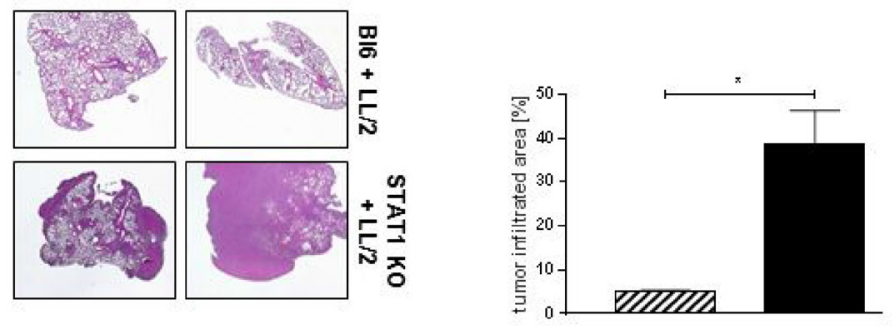

Figure 3: STAT1 deficiency is associated with induced tumor development. (A) Experimental design for the induction of experimental lung adenocarcinoma. Mice were injected with $1 \times 10^{6} \mathrm{LL} / 2$-luc-M38 cells (LL/2 cells) intravenously (i.v.). Tumor development was measured with the help of an in vivo bioluminescence imaging system at described days. Experiment ended at day 14 to day 20. (B) Stat1 mRNA was measured in total lung cells of tumor bearing B16/C67j (B16) mice at day 13 and day 17 after lung tumor induction. Stat1 mRNA level decreases during the progression of lung adenocarcinoma in total lung cells $\left(\mathrm{n}_{\mathrm{B} 16}=4 ; \mathrm{n}_{\mathrm{Bl} 6+\mathrm{LL} / 2 \mathrm{~d} 14}=5\right.$; $\left.\mathrm{n}_{\mathrm{B} 16+\mathrm{LL} / 2 \mathrm{~d} 17}=2\right)$. $(\mathbf{C})$ Loss of STAT1 leads to a significantly increased tumor development compared to tumor bearing wild-type mice $\left(\mathrm{n}_{\mathrm{B} 16+\mathrm{LL} / 2}=10 ; \mathrm{n}_{\mathrm{STAT} 1 \mathrm{KO}+\mathrm{LL} / 2}=9\right)$. Both groups showed comparable disease incidence and no mortality. Two of four representative experiments are shown. (D) Hematoxylin and Eosin (H\&E) showed increased tumor infiltrated area in STAT1 knockout (STAT1 KO) mice compared to

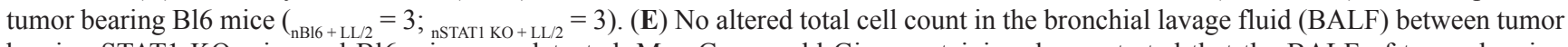
bearing STAT1 KO mice and B16 mice was detected. May-Gruenwald-Giemsa staining demonstrated that the BALF of tumor bearing STAT1 KO mice is characterized by a strong infiltration of immune cells, especially by monocytes and macrophages $\left(\mathrm{n}_{\mathrm{Bl} 6+\mathrm{LL} / 2}=5{ }_{\mathrm{nSTAT1} \text { KO }}\right.$ $+\mathrm{LL} / 2=5)$. Data are presented as mean values \pm SEM; unpaired $t$-test ${ }^{*} p<0.05,{ }^{* *} p<0.01,{ }^{* * *} p<0.001$. 
significantly increased cell viability compared to LL/2luc-M38 cells that were incubated with $\mathrm{CM}$ derived from wild-type M1-like macrophages (Supplementary Figure 3F).

\section{STAT1 deficiency is associated with accumulation of $\mathrm{PD}-\mathrm{L1}^{+}$macrophages in tumor bearing mice}

As we could observe that the loss of STAT1 leads to a defect in M1 macrophages in the bone marrow in naïve mice, we next wanted to investigate the consequences of this phenomenon in our murine model of lung adenocarcinoma model. We first found a strong

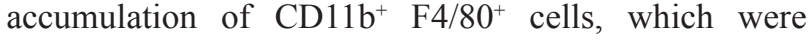
previously gated on $\mathrm{CD}^{-}$- cells in the lungs of tumor bearing STAT1 KO mice compared to tumor bearing wild-type control (Figure 4A). Here we found that these lung tumor infiltrating macrophages $\left(\mathrm{CD} 11 \mathrm{~b}^{+} \mathrm{F} 4 / 80^{+}\right.$ gated on $\mathrm{CD}^{-}$) strongly expressed PD-L1 in tumor bearing STAT1 KO mice compared to tumor bearing Bl6/C67j mice (Figure 4B). Supernatants from total lung cells derived from tumor bearing mice showed that an increased secretion of IL-10 in STAT1 KO mice compared to wild-type controls (Figure 4C). As we found a defect in Nos 2 expression in Stat1 deficient M1 macrophages (Supplementary Figure 3B), we next wanted to analyze Interferon Regulatory Factor 1 (IRF1). IRF1 is described to be able to directly induce NO synthase [24] and is therefore an important factor to eliminate tumor cells. Indeed, we found a strong reduction of Irfl mRNA level in total lung cells derived from tumor bearing STAT1 KO mice compared to tumor bearing wild-type controls (Figure 4D). In order to verify that the upregulation of PD-L1 on Stat1 deficient macrophages, increased IL-10 secretion and impaired Irfl expression also impairs the killing function of Stat 1 deficient macrophages, we next isolated $\mathrm{CD} 11 \mathrm{~b}^{+}$cells from tumor bearing lungs. Purity of isolated $\mathrm{CD}_{11 \mathrm{~b}^{+}}$was analysed via flow cytometry and a purity of around $90 \%$ was detected (Supplementary Figure 4A). LL/2-luc-M38 cells were incubated with conditioned medium $(\mathrm{CM})$ derived from isolated CD11b culture. CM was diluted in DMEM medium. LL/2luc-M38 cells were incubated with a $20 \%$ dilution of CM derived from $\mathrm{CD} 11 \mathrm{~b}$ culture. In line with our previous results, cell viability of LL/2-luc-M38 cells was higher when incubated with $\mathrm{CM}$ derived from tumor bearing

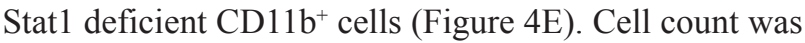
determined via a standard curve (Supplementary Figure 4C). To strengthen our results, we repeated differentiation assay of M1 macrophages but in tumor bearing mice. Similar to our results in naïve mice, we found a strong downregulation of Nos 2 expression in Stat 1 deficient M1 macrophages derived from tumor bearing mice (Figure $4 \mathrm{~F})$ as well as decreased secretion of soluble TNF $\alpha$ in the supernatant derived from M1 macrophages differentiated from tumor bearing STAT1 KO mice (Figure 4G). In accordance to these findings LL/2-luc-M38 cell viability assay showed an increased survival of murine tumor cells, when incubated with $\mathrm{CM}$ derived from Stat 1 deficient M1 macrophages (Figure 4H).

\section{Impaired activation of cytotoxic $T$ cells infiltrating the tumor of Stat1 deficient mice}

Macrophages are able to modulate antigen crosspresentation and $\mathrm{T}$ cell activation. Previous studies demonstrated that macrophages are able to activate $\mathrm{CD} 8^{+} \mathrm{T}$ cells for proliferation and $\mathrm{T}$ cells cytokine production [25]. Since we could clearly demonstrate a defect in the killing capacity of Stat1 deficient macrophages, we next wanted to investigate whether this defect also has consequences for $\mathrm{T}$ cell activation. Indeed, we found a reduced number of Tbet $^{+}$Eomes $^{+}$cells previously gated on $\mathrm{CD} 8^{+}$cells in tumor bearing lungs from STAT1 KO mice (Figure 5A). Further on, we could demonstrate that tumor bearing lungs from STAT1 KO mice are significantly less infiltrated by $\mathrm{CD} 8^{+}$ $\mathrm{TNF} \alpha^{+} \mathrm{T}$ cells compared to tumor bearing B16/C57j mice (Figure 5B). mRNA analysis of total lung cells derived from tumor bearing mice showed that STAT1 KO mice have a strong downregulation of Eomes (Figure 5C), Tnf (Figure 5D) and Perforin (Figure 5E) compared to total lung cells derived from tumor bearing wild-type mice. In order to analyze whether the observed effect is based on impaired activation of $\mathrm{CD}^{+} \mathrm{T}$ cells because of impaired macrophage function or if Stat 1 deficiency leads to impaired CD8+ T cells activation we isolated $\mathrm{CD} 8^{+} \mathrm{T}$ cells from tumor bearing STAT1 KO mice. CM derived from CD8+ T cell culture was diluted in DMEM medium and LL/2-luc-M38 cells were cultured with $20 \% \mathrm{CM}$ and cell viability was analyzed after $24 \mathrm{~h}$ (Figure 5F, Supplementary Figure 5A). No difference was detected in cell viability of LL/2-luc-M38 cells between incubation with $\mathrm{CM}$ obtained from Stat1 deficient $\mathrm{CD} 8^{+} \mathrm{T}$ cells and $\mathrm{CM}$ derived from $\mathrm{CD} 8^{+} \mathrm{T}$ cells from B16/C57j mice (Figure 5G). As positive control CM from CTLL2 cells was used (Supplementary Figure 5C). Purity of isolated $\mathrm{CD} 8^{+} \mathrm{T}$ cells from tumor bearing lungs was similar between both mice strains (Supplementary Figure 4B). Cell count was determined via a standard curve (Supplementary Figure 5B). In order to strengthen our hypothesis that Stat1 deficiency had no impact on $\mathrm{CD} 8^{+} \mathrm{T}$ cells but Stat 1 deficient macrophages, were not able to recruit $\mathrm{CD} 8^{+}$cells in the tumor microenvironment we also isolated lung $\mathrm{CD} 8^{+}$cells from naïve STAT1 KO mice and $\mathrm{B} 16 / \mathrm{C} 57 \mathrm{j}$ mice. $\mathrm{CM}$ from naïve lung $\mathrm{CD} 8^{+} \mathrm{T}$ cells from STAT1 KO mice or B16/C57j mice was diluted in to $20 \%$ or $50 \% \mathrm{CM}$. No difference in cell viability of murine lung cancer was detected when LL/2-luc-M38 cells were incubated with either $\mathrm{CM}$ from naïve lung $\mathrm{CD} 8^{+} \mathrm{T}$ cells from STAT1 KO or wild-type mice (Supplementary Figure 5D). Cell vitality was determined via standard curve (Supplementary Figure 5B). We further on, could 
demonstrate that there is no difference in apoptosis between isolated lung $\mathrm{CD}^{+} \mathrm{T}$ cells derived from naïve STAT1 $\mathrm{KO}$ mice or naïve wild-type mice (Supplementary Figure 5E).

\section{Stat1 deficiency leads to an upregulation of suppressive $T$ cells in the tumor microenvironment}

As we found a significant upregulation of PD-L1 in the lung tumor microenvironment of STAT1 KO mice, we next asked about the influence of STAT1 on PD-1. PD-1 is the main binding partner to PD-L1 [22]. It has been previously reported that the PD-1/ PDL1 signaling pathway promotes the proliferation, maintenance and suppressive function of $\mathrm{T}$ regulatory cells (Tregs) located in the tumor microenvironment [26]. Therefore, we next started to analyse regulatory $\mathrm{T}$ cells in tumor bearing STAT1 KO mice. First, we found a significantly increased secretion of IL-2 from total lung cells derived from tumor bearing STAT1 KO mice compared to tumor bearing B16/
A

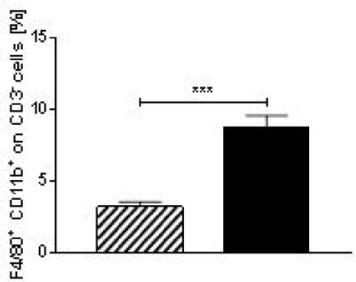

C

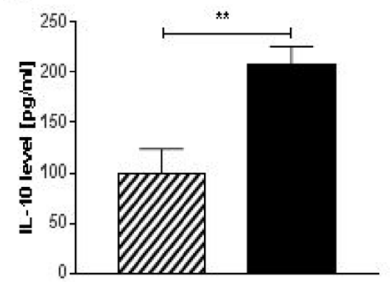

$\mathbf{F}$

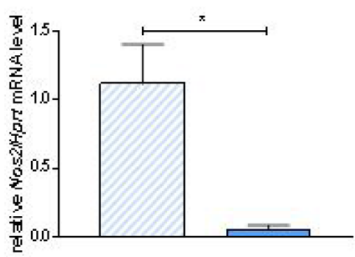

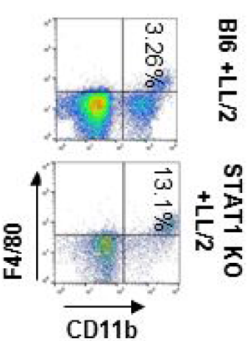

D
B

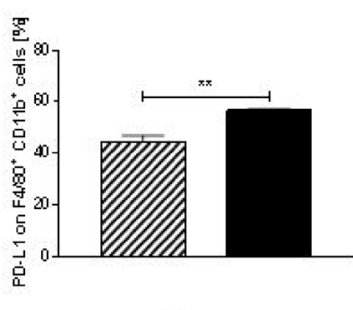

E

BI6+LL/2

- STAT $1 \mathrm{KO}+\mathrm{LL} / 2$

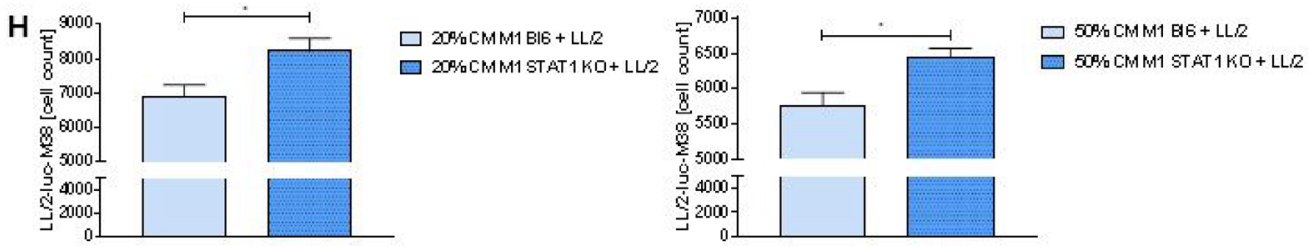

Figure 4: Loss of STAT1 is associated with increased infiltration of tumor associated macrophages and PD-L1

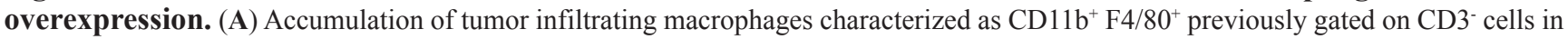
tumor bearing Stat1 deficient mice compared to tumor bearing WT mice $\left(\mathrm{n}_{\mathrm{B} 16+\mathrm{LL} / 2}=11 ; \mathrm{n}_{\mathrm{STAT1} \mathrm{KO}+\mathrm{LL} / 2}=11\right)$. (B) Loss of Stat 1 leads to an overexpression of PD-L1 on lung tumor infiltrating macrophages $\left(\mathrm{CD} 11 \mathrm{~b}^{+} \mathrm{F} 4 / 80^{+}\right)$during lung adenocarcinoma development compared to wild-type controls $\left(\mathrm{n}_{\mathrm{B} 16+\mathrm{LL} / 2}=11 ; \mathrm{n}_{\mathrm{STAT} 1 \mathrm{KO}+\mathrm{LL} / 2}=11\right)$. (C) Significantly enhanced secretion of IL-10 from total lung cells was measured in the supernatants of tumor bearing STAT1 KO mice compared to Bl6 mice $\left(\mathrm{n}_{\mathrm{Bl} 16+\mathrm{LL} / 2}=9 ; \mathrm{n}_{\mathrm{STAT} 1 \mathrm{KO}+\mathrm{LL} / 2}=9\right)$. (D) Loss of Stat1 leads to a significantly decreased expression of Irfl in total lung cells of tumor bearing mice compared to Bl6 controls $\left(\mathrm{n}_{\mathrm{Bl} / \mathrm{LL} / 2}=4 ; \mathrm{n}_{\mathrm{STATl} \mathrm{KO}+\mathrm{LL} / 2}=5\right)$. (E) Conditioned medium (CM) from CD11b tumor infiltrating macrophages from Stat1 deficient mice failed to reduce cell viability of LL/2-luc-M38 cells compared to CD11 b derived from tumor bearing B16 mice $\left(\mathrm{n}_{\mathrm{B} 16+\mathrm{LL} / 2}=3 ; \mathrm{n}_{\mathrm{STAT} 1 \mathrm{KO}+\mathrm{LL} / 2}=3\right)$. (F) Loss of Stat1 leads to a defect of Nos 2 expression on M1 like bone marrow derived macrophages in tumor bearing mice $\left(\mathrm{n}_{\mathrm{Bl} 6+\mathrm{LL} / 2}=10 ; \mathrm{n}_{\mathrm{STAT} 1 \mathrm{KO}+\mathrm{LL} / 2}=6\right)$. $(\mathbf{G})$ M1-like bone marrow derived macrophages derived from tumor bearing STAT1 KO secreted significant lower levels of soluble TNF $\alpha$ compared to M1 macrophages derived from tumor bearing B16 mice $\left(\mathrm{n}_{\mathrm{Bl} 6+\mathrm{LL} / 2}=7 ; \mathrm{n}_{\mathrm{STAT} 1 \mathrm{KO}+\mathrm{LL} / 2}=7\right)$. $(\mathbf{H})$ Enhanced LL/2-luc-M38 cell viability was detected when lung adenocarcinoma cells were incubated with CM of M1 macrophages derived from tumor bearing STAT1 $\mathrm{KO}$ mice compared to tumor bearing wild-type mice $\left(\mathrm{n}_{\mathrm{Bl} 6+\mathrm{LL} / 2}=10 ; \mathrm{n}_{\mathrm{STAT} 1 \mathrm{KO}+\mathrm{LL} / 2}=6\right)$. Data are presented as mean values $\pm \mathrm{SEM} ;$ unpaired $t$-test ${ }^{*} p<0.05,{ }^{* *} p<0.01,{ }^{* * *} p<0.001$. 
C57j mice (Figure 6A). Interestingly, we could not find an alteration in $\mathrm{Foxp}^{+} \mathrm{CD}^{+}$previously gated on $\mathrm{CD}^{+}$ CD25 $5^{+}$tumor infiltrating $\mathrm{T}$ cells between both mice strains (Supplementary Figure 6A) but an enhanced accumulation of $\mathrm{CD}^{+} \mathrm{PD}-1^{+} \mathrm{T}$ cells in the lung tumors of STAT1 KO mice (Figure 6B). Moreover, we found a significantly increased mRNA expression of the suppressive surface marker CD278 (Icos) in total lung cells derived from tumor bearing STAT1 KO mice compared to tumor bearing wild-type mice (Figure 6C) but no alteration was found on Ctla4 mRNA expression between both mice strains (Supplementary Figure 6B). Since we found a strong upregulation of suppressive markers, we next asked whether cytotoxic function was affected by Stat1 deficiency. We first found that, tumor infiltrating CD4+ $\mathrm{T}$ cells show no difference in the expression of the TNFR I (Supplementary Figure 6C) but a downregulation of the TNFR II was detected on $\mathrm{CD}^{+} \mathrm{T}$ cells in the lungs of tumor bearing STAT1 KO mice compared to tumor bearing
$\mathrm{B} 16 / \mathrm{C} 57 \mathrm{j}$ mice (Figure 6D). In line with this finding, we found a reduced production of TNF $\alpha$ by tumor infiltrating Stat 1 deficient $\mathrm{CD}^{+}$cells (Figure 6E).

In conclusion, these results indicate that the loss of STAT1 leads to an upregulation of PD-L1, especially on tumor infiltrating macrophages, which is probably linked to a more suppressive tumor microenvironment characterized by CD4+PD1+T cells and a dysfunctional recruitment of cytotoxic $\mathrm{CD} 8^{+} \mathrm{T}$ cells in the tumor. Further on, reduced $\mathrm{TNF} \alpha$ secretion seems to be associated with the inability of tumor infiltrating lymphocytes and macrophages to directly kill the LL/2-luc-M38 tumor cells.

\section{DISCUSSION}

One of the major limitation in the use of ICB therapies is the low percentage of patients that
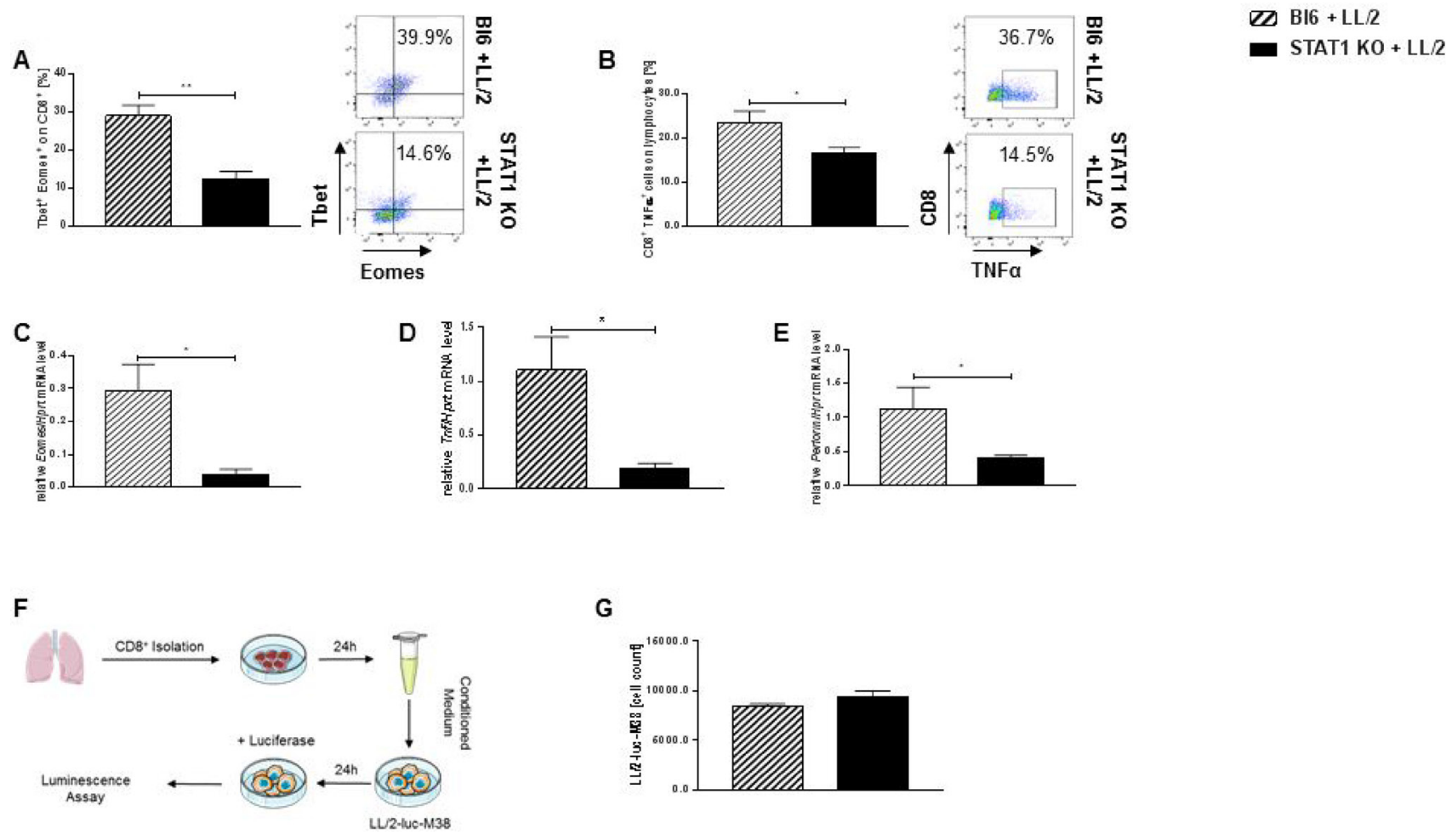

Figure 5: Loss of Stat1 negatively impairs cytotoxic capacity of tumor infiltrating CD8 $^{+} \mathbf{T}$ lymphocytes. (A) Dramatic reduction of Tbet $^{+}$Eomes $^{+}$previously gated on $\mathrm{CD} 8^{+}$cytotoxic lymphocytes in the lungs of tumor bearing STAT1 KO mice compared to $\mathrm{CD}^{+}$tumor infiltrating T lymphocytes in tumor bearing B16 mice $\left(\mathrm{n}_{\mathrm{Bl}+\mathrm{LL} / 2}=6 ; \mathrm{n}_{\mathrm{STAT1} \mathrm{KO}+\mathrm{LL} / 2}=5\right)$. (B) Stat1 deficiency resulted in a decreased capability of lung $\mathrm{CD}^{+} \mathrm{T}$ lymphocytes to produce $\mathrm{TNF} \alpha$ during lung tumor development compared to tumor bearing wild-type controls $\left(\mathrm{n}_{\mathrm{Bl} 6+\mathrm{LL} / 2}=6 ; \mathrm{n}_{\mathrm{STAT1} \text { KO }+\mathrm{LL} / 2}=6\right)$. (C) Eomes mRNA level were significantly reduced in total lung cells from Stat 1 deficient mice compared to tumor bearing Bl6 mice $\left(\mathrm{n}_{\mathrm{B} 16+\mathrm{LL} / 2}=4 ; \mathrm{n}_{\mathrm{STAT} 1 \mathrm{KO}+\mathrm{LL} / 2}=5\right)$. (D) Loss of Stat1 leads to a reduced mRNA expression of Tnf in total lungs cells compared to total lung cells derived from tumor bearing wild-type mice $\left(\mathrm{n}_{\mathrm{B} 16+\mathrm{LL} / 2}=4 ; \mathrm{n}_{\mathrm{STAT} 1 \mathrm{KO}+\mathrm{LL} / 2}=5\right)$. (E) Stat1 deficiency leads to a downregulation of Perforin mRNA expression in total lung cells derived from tumor bearing mice $\left(\mathrm{n}_{\mathrm{Bl} / 6+\mathrm{LL} / 2}=4 ; \mathrm{n}_{\mathrm{STATl} \mathrm{KO}+\mathrm{LL} / 2}=5\right)$. (F) Experimental design of an in vitro bioluminescence cytotoxic assay. $\mathrm{CD}^{+} \mathrm{T}$ cells were purified from tumor bearing lungs of $\mathrm{B} 16$ and STAT1 KO mice. Supernatants from CD8 ${ }^{+} \mathrm{T}$ cells were diluted with DMEM (conditioned medium $=\mathrm{CM}$ ). LL/2-luc-M38 cells were cultured for $24 \mathrm{~h}$ with CM. Cell viability was detected via bioluminescence. (G) No alteration in the cell viability of LL/2-luc-M28 lung adenocarcinoma cells co-cultured with $\mathrm{CM}$ from $\mathrm{CD} 8^{+}$tumor infiltrating $\mathrm{T}$ lymphocytes between $\mathrm{STAT} 1 \mathrm{KO}$ and $\mathrm{Bl6}$ mice $\left(\mathrm{n}_{\mathrm{B} 16+\mathrm{LL} / 2}=3\right.$; $\mathrm{n}_{\mathrm{STAT} 1 \mathrm{KO}+\mathrm{LL} / 2}=3$ ). Data are presented as mean values $\pm \mathrm{SEM}$; unpaired $t$-test ${ }^{*} p<0.05,{ }^{* *} p<0.01,{ }^{* * *} p<0.001$. 
successfully respond to ICB [10-12]. Beside the problem that patients do not benefit from treatment resistance mechanisms are defined as adaptive immune resistance and acquired immune resistance. One documented case is the constitutive expression of PD-L1 that may inhibit antitumoural $\mathrm{T}$ cell responses. However, it is controversially discussed whether constitutive expression of PD-L1 is associate with increased or decreased likelihood to respond to immunotherapy [27]. In our murine model of lung adenocarcinoma in vivo blockade of PD-L1 resulted in an upregulation of PD-1 in tumour infiltrating T lymphocytes. PD-1 is known to induce T cell exhaustion which further on negatively influences the activation state and cytotoxic properties of cytotoxic T lymphocytes [28]. In line with this we found increased infiltration of PD- $1^{+} \mathrm{T}$ cells in the tumor microenvironment and reduced production of TNF $\alpha$ by $\mathrm{CD}^{+}$and $\mathrm{CD}^{+} \mathrm{T}$ cells in the lung of STAT $1-/-$ mice bearing tumour. TNF $\alpha$ has been previously described as an important anti-tumoural molecule to induce apoptosis in our murine lung adenocarcinoma cell line LL/2-luc-M38 [19]. Reduced TNFa secretion is also linked to the inability to suppress tumor cell proliferation and to induce tumor progression. Further on, reduced TNF $\alpha$ is described to lead to impaired recruitment of lymphocytes in the tumor [29] and therefore is associated with enhanced tumor development. In general, TNF $\alpha$ is a pleiotropic cytokine, characterized with antitumoural and protumoural functions [5]. It exists in two isoforms, a transmembrane bound $\mathrm{TNF} \alpha$ and a soluble form [30]. Both isoforms, soluble and transmembrane bind to the TNF receptor (TNFR) I and TNFR II $[31,32]$. In our murine lung cancer model, we found a significantly reduced secretion of soluble TNF $\alpha$ by M1 macrophages and impaired secretion of soluble TNF $\alpha$ by $\mathrm{CD}^{+}$and $\mathrm{CD}^{+} \mathrm{T}$ cells. Of note, the transmembrane isoform of TNF $\alpha$ is also able to kill tumor cells [33]. Since we found a downregulation of the TNFR
A

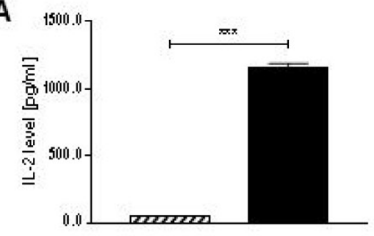

C

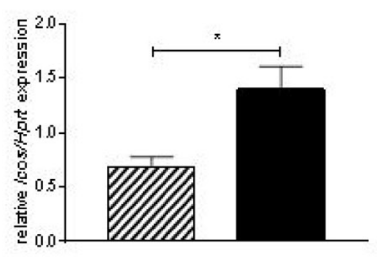

B

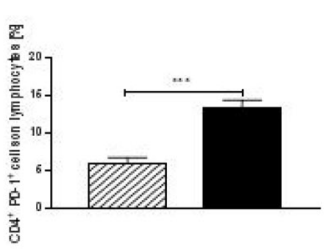

D

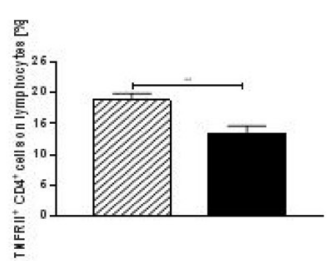

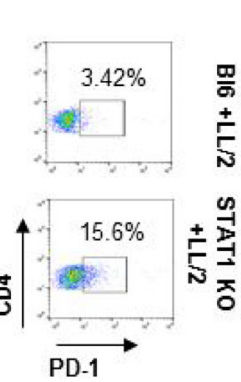

Z7 BI6 + LL/2

- STAT1 KO+ LL/2

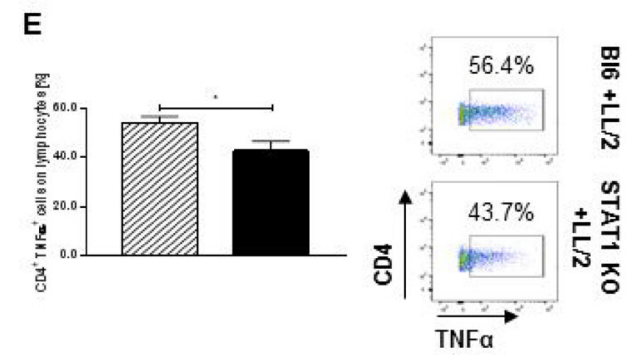

Figure 6: Stat1 deficiency negatively impacts cytotoxic CD4 ${ }^{+}$tumor infiltrating T lymphocytes. (A) Total lung cells isolated from tumor bearing STAT1 KO mice secreted higher levels of IL-2 compared to total lung cells derived from tumor bearing B16 mice $\left(\mathrm{n}_{\mathrm{Bl} 6+\mathrm{LL} / 2}=5 ; \mathrm{n}_{\mathrm{STAT1} \text { кО }+\mathrm{LL} / 2}=5\right)$. (B) CD4 $4^{+}$tumor infiltrating lymphocytes strongly upregulated PD-1 in tumor bearing STAT1 KO mice compared to tumor bearing controls $\left(\mathrm{n}_{\mathrm{B} 16+\mathrm{LL} / 2}=5 ; \mathrm{n}_{\mathrm{STAT} 1 \mathrm{KO}+\mathrm{LL} / 2}=4\right)$. (C) Stat1 deficiency leads to an increase of Icos in mRNA derived from total lung cells of tumor bearing mice compared to tumor bearing Bl6 mice $\left(\mathrm{n}_{\mathrm{Bl} / \mathrm{LL} / 2}=4 ; \mathrm{n}_{\mathrm{STAT1} \mathrm{KO}+\mathrm{LL} / 2}=4\right)$. (D) Loss of Stat1 leads to a defect of TNF $\alpha$ production in $\mathrm{CD} 4^{+}$tumor infiltrating lymphocytes $\left(\mathrm{n}_{\mathrm{Bl} 6+\mathrm{LL} / 2}=6 ; \mathrm{n}_{\mathrm{STAT} 1 \mathrm{KO}+\mathrm{LL} / 2}=6\right)$. (E) Tumor infiltrating CD4 $4^{+}$ T lymphocytes of STAT1 KO mice express lower numbers of the TNFR II compared to tumor bearing wild-type controls $\left(\mathrm{n}_{\mathrm{Bl} 6+\mathrm{LL} / 2}=6\right.$; $\mathrm{n}_{\mathrm{STAT} 1 \mathrm{KO}+\mathrm{LL} / 2}=6$ ). Data are presented as mean values $\pm \mathrm{SEM}$; unpaired -test ${ }^{*} p<0.05,{ }^{* *} p<0.01,{ }^{* * *} p<0.001$. 
II but an unaltered expression of TNFR I in tumor bearing STAT1 KO mice, it is notably that the transmembrane form of TNF $\alpha$ is able to exerts its cytotoxicity via both receptors. However, previous reports show that STAT1 mediates the transmembrane TNF $\alpha$ induced formation of death inducing signaling complex and apoptosis via the TNFR I [34]. Taken together the loss of Stat1 leads to an impaired TNF $\alpha$ mediated immune signaling, resulting in a complete defect to kill tumor cells in our murine model of lung adenocarcinoma. Previous studies in melanoma patients used TNF $\alpha$ antibodies to overcome the resistance to anti-PD-1 therapy [35]. Our results showed that in NSCLC the blockade of TNF $\alpha$ would favor the tumor growth and probably would show a completely different effect as in melanoma treatment and which further on demonstrated the dual effects of TNF $\alpha$ in different cancer types. Further experiments in this direction are needed. Moreover, we could demonstrate that a successful blockade of PD-1 is associated with a trend to increased Stat1 expression in total lung cells derived from tumor bearing mice. Additionally, we demonstrated in our murine lung cancer model and our human patient cohort that increased expression of STAT1 is associated with decreased tumor size. In our human patient cohort, we found this inverse correlation especially for the STAT1 $\beta$ isoform. STAT $1 \alpha$ and STAT $1 \beta$ are both able to accumulate on the IFN $\gamma$-induced IRF-1 promotor, which was demonstrated by in vivo chromatin immunoprecipitation but one of the main differences is that only STAT $1 \alpha$ is capable to recruit CBP (CREB binding protein)/p300 and to stimulate transcription [36]. The function of $\mathrm{CBP} / \mathrm{p} 300$ is highly discussed. These proteins appear to contribute to certain tumor-suppressor pathways but both proteins are also essential for the actions of many oncogenes [37]. As STAT $1 \alpha$ only correlates inversely with the tumor size in the TU region of NSCLC patients, this phenomenon might be explained by controversial function of the $\mathrm{CBP} / \mathrm{p} 300$ proteins, recruited by STAT $1 \alpha$ in the CTR and TU from patients suffered from NSCLC, probably depending on the different microenvironment. Another important aspect for STAT1 $\beta$ being the more successful key marker in tumor defense than STAT $1 \alpha$ is the fact that STAT $1 \beta$ acts as a dominant negative regulator in IFN $\gamma$ signaling [38] and that the best characterized signaling axis for PD-L1 is its induction mediated by IFN $\gamma[1]$.

All these results indicate STAT1 as a potential new key target for successful combinatory ICB.

\section{MATERIALS AND METHODS}

\section{Human subjects and study population}

This study was performed at the FriedrichAlexander-Universität Erlangen-Nürnberg in Geramany and was approved by the ethics review board of the Friedrich-Alexander-Universität Erlangen-Nürnberg (Re-
No: 56_12B; DRKS-ID: DRKS00005376). Sixty-five patients that suffered from NSCLC underwent surgery and gave their approval to be enrolled in this study in an informed written consent. The patients were conducted in accordance with the ethical guidelines of the Declaration of Helsinki. The diagnosis of lung cancer was based on pathological confirmation. The histological classification of lung cancers was performed in accordance to the WHO (World Health Organization), formulated in 2004. TNM classification of patients that suffered from NSCLC was performed in accordance to the International Association for the Study of Lung Cancer (IASLC) in 2010. During lung surgery, three regions were taken: the tumoural region (TU: solid tumor tissue), the peri-tumoural region (PT: up to $2 \mathrm{~cm}$ away from the solid tumor) and a tumor free control regin (CTR: at least $5 \mathrm{~cm}$ away from the solid tumor). This cohort of NSCLC patients was previously derived in [16].

\section{Protein extraction and Western blot analysis}

For protein extraction, lung tissue samples were lysed in RIPA buffer (Thermo Fisher Scientific, Waltham, MA, USA) added with an inhibitor cocktail (Roche Diagnostics, Mannheim, Germany). Lung tissue samples were homogenized using SpeedMill PLUS (Analytik Jena, Jena, Germany) and innuSPEED lysis Tube P (Analytik Jena). After homogenization samples were centrifuged ( $5 \mathrm{~min}, 3000 \mathrm{rpm}, 4^{\circ} \mathrm{C}$ ), supernatants were collected and incubated on ice for $45 \mathrm{~min}$ followed by centrifugation (5 min, $3000 \mathrm{rpm}, 4^{\circ} \mathrm{C}$; $45 \mathrm{~min}$, full speed, $4^{\circ} \mathrm{C}$ ). Protein concentration was determined using Bradford Assay (Protein Assay Dye Reagent Concentration, BioRad, Munich, Germany). Western blot analysis to detect Phospho-STAT1 Tyr701 (1/1000, cell signaling, Danvers, MA, USA), PD-L1 E1L3N (1/1000, cell signaling) and b-Actin (1/500, sc-1616, Santa Cruz, TX, USA) was performed as described in [39] with $50 \mu \mathrm{g}$ of total protein. Quantification of total p-Tyr-STAT1 and PD-L1 was performed using AlphaView Software for FluorChem Systems (Biozym Scientific, Oldendorf, Germany).

\section{Cell lines}

The murine lung adenocarcinoma cell line LL/2luc-M38 was purchased and authenticated from Caliper LifeScience (Bioware cell line, Caliper LifeScience, Waltham, MA, USA). All Caliper LifeScience cell lines are confirmed to be pathogen-free by IMPACT profile I (PCR) at the University of Missouri Research Animal Diagnostic and Investigation Laboratory. Luciferase expression is coupled to a neomycin-resistance gene which renders the cell resistant to geneticin (G418). In order to select only luciferase expressing tumor cells, LL/2-luc-M38 cells were treated periodically with G418 solution $(500 \mu \mathrm{g} / \mathrm{ml}$, SigmaAldrich, Taufkirchen, Germany). Three to four cell passages 
between thawing and usage were performed before cells were injected into the tail vein. LL/2-luc-M38 cells were cultured in DMEM (Thermo Fisher Scientific) supplemented with $10 \%$ FCS, $1 \%$ Pen/Strep and $1 \% 1-$ Glut at $37^{\circ} \mathrm{C}$ and $5 \% \mathrm{CO}_{2}$. Mycoplasma contamination was detected using Mycoplasma Detection Kit (Absource Diagnostics GmbH) according to the manufacturer's instructions (latest test: August, 9th, 2016).

The murine CTLL2 cell line was kindly provided to use by PD Dr. Ulrike Schleicher from the Institute of Microbiology, Universitätsklinikum Erlangen-Nürnberg. Cells were cultured in RPMI-1640 medium (Gibco, Thermo Fisher Scientific) supplemented with 10\% FCS, 1\% Pen-Strep, 1\% L-Glut and 4 ng/ml IL-2 (PeproTech, $\mathrm{GmbH}$, Hamburg, Germany) at $37^{\circ} \mathrm{C}$ and $5 \% \mathrm{CO}_{2}$.

\section{RNA isolation and cDNA synthesis}

Human lung tissues were homogenized with the usage of Precellys Lysing Kits (Bertin Technologies, Montigny-le-Bretonneux, France) using the benchtop homogenizer Minilys (Bertin Technologies) as written in the manufacturer's instructions. Total RNA derived from human samples and murine cells was isolated using peqGold RNA Pure (Peqlab, Erlangen, Germany) in accordance to the manufacturer's protocol. RNA was reverse-transcribed into cDNA using RevertAid ${ }^{\mathrm{TM}}$ First Strand cDNA Synthesis Kit (Fermentas, St. Leon-Rot, Germany) in accordance to the manufacturer's protocol.

\section{Quantitative real-time PCR (qPCR)}

qPCR was performed with cDNA using iTaq Universal SYBR Green Supermix (BioRad, Munich, Germany) in a total volume of $20 \mu \mathrm{l}$. qPCR primers were designed and purchased at Eurofins-MWG-Operon, Ebersberg, Germany. Reactions (50 cycles, initial activation at $98^{\circ} \mathrm{C}, 2 \mathrm{~min}$, denaturation at $95^{\circ} \mathrm{C}, 5 \mathrm{~min}$, hybridization at $60^{\circ} \mathrm{C}, 10 \mathrm{~min}$ ) were performed using the CFX-96 Real-time PCR Detection System (BioRad) and analysed by the CFX Manager Software (BioRad). Relative quantification was performed using the 2- $\Delta \Delta \mathrm{CT}$ method, Hprt (hypoxanthine-guanine-phosphoribosyltransferase was used as a housekeeping gene. The following sequences were used for human qPCR analysis: HPRT for 5'-TGACACTGGCAAAACAATGCA-3' rev 5'-GGTCCTTTTCACCAGCAAGCT-3'; PDL1 for 5'-AGCAAAGTGATACACATTTTGGAG-3' rev 5'-CC CCGATGAACCCCTAAACC-3', STAT1 $\alpha$ for 5'-CAC CAGAGCCAATGGAACTT-3' rev 5'-ACAGAGCCCA CTATCCGAGA-3', STAT1 $\beta$ for 5'-CTTTCCCTGACAT CATTCGCA-3' rev 5'-AAGGCTGGCTTGAGGTTTGT A-3'. For murine qPCR analysis the following primers were used: Hprt: for 5'-GCCCCAAAAT GGTTAAGGTT-3' rev 5'-TTGCGCTCATCTTAGGCT TT-3'; Nos 2: for 5'-AGACCTCAACAGAGCCCTCA-3' rev 5'-TCGAAGGTGAGCTGAACGAG-3'; Tnf: for 5'-AGCCCCCAGTCTGTATCCTT-3' rev 5'-CTCCCT TTGCAGAACTCAGG-3'; Perforin for 5'-GATGTG AACCCTAGGCCAGA-3' rev 5'-GGTTTTTGTACCA GGCGAAA-3'; Tbet for 5'-TTCCCATTCCTGTCCTT CACCG-3' rev 5'-GGAAGGTCGGGGTAAAAAC-3'; Ctla4 for 5'-GGATCCTTGTCGCAGTTAGC-3' rev 5'-TCACATTCTGGCTCTGTTGG-3'; Icos for 5'-GTGC AGCTTTCGTTGTGGTA-3' rev 5'-TCAGGGGAACTA GTCCATGC-3'; Stat1 for 5'-CATGGCTGCCGAGAACA TAC-3' rev 5'-TCTGGTGCTTCCTTTGGTCT -3'; Stat2 for 5'-TCAGACTTACCAGGCTTCCG-3'rev 5'-GTCAAGAAGCCGAAGTCCCA-3'; Stat3 for 5'-GCT TCC TGC AAG AGT CGA AT-3' rev 5'-ATT GGC TTC TCA AGA TAC CTG-3'.

\section{Luminescence/cell viability assay}

$7 \times 10^{\wedge} \mathrm{LL} / 2$-luc-M38 cells were seeded in a 96 well plate and incubated for $24 \mathrm{~h}$ at $37^{\circ} \mathrm{C}, 5 \% \mathrm{CO}_{2}$ in DMEM supplemented with 10\% FCS, 1\% L-Glut and $1 \%$ Pen/Strep. After $24 \mathrm{~h}$ medium was removed and LL/2luc-M38 cells were washed with PBS and incubated with $20 \%$ or $50 \%$ conditioned medium (CM) derived from M1 macrophage culture or $\mathrm{CD}^{+}$cell culture diluted in DMEM plus supplements. After another $24 \mathrm{~h}$ incubation at $37^{\circ} \mathrm{C}, 5 \% \mathrm{CO}_{2}$, conditioned medium was removed and LL/2-luc-M38 were incubated with a $15 \mu \mathrm{g} / \mathrm{ml}$ luciferin (Promega, Mannheim, Germany) solution (diluted in PBS) to detect luminescence intensity using Centro $\mathrm{XS}^{3}$ LP 960 Mircoplate Luminometer (Berthold Technologies, Bad Widlbach, Germany). Detected luminescence is proportional to the living cell number. Cell viability is therefore calculated via standard curve.

\section{ELISA}

Enzyme-linked immunosorbent assay (ELISA) was used to detect the cytokine concentration in cell culture supernatants. ELISA was performed in accordance to the manufacturer's protocol. Murine IL-2, IL-10 and TNF $\alpha$ ELISA Duo Sets were purchased from BD BioScience.

\section{Mice}

STAT1 knockout (KO) mice were kindly donated by Dr. Chiriac from the Department Medicine 1, Universitätsklinikum Erlangen-Nürnberg. STAT1 KO mice are on $\mathrm{B} 16 / \mathrm{C} 57 \mathrm{j}$ background. B16/C57j mice and STAT1 KO mice were bred in house under a $12 \mathrm{~h}$ light/dark cycle at the local animal care facility of the Friedrich-Alexander-Universität Erlangen-Nürnberg, Hartmannstraße 14, 91052 Erlangen. Food and water were provided ad libitum. All animal procedures were approved by the respective government in accordance to the German animal protection law and carried out by skilled experimenters (Az 55.2-2532.1-36/13). 


\section{Murine model of lung adenocarcinoma and in vivo imaging}

LL/2-luc-M38 cells were cultured in DMEM supplemented with $10 \%$ FCS, $1 \%$ L-Glut and $1 \%$ Pen/ Strep. $1 \times 10^{\wedge}{ }^{\circ} \mathrm{LL} / 2$-luc-M38 in a total volume of 200 $\mu 1$ DMEM without any supplements were injected intravenously into the tail vein of 6-8 weeks old, female mice. At described time points, mice were shaved and weighted and luciferin $(0.15 \mathrm{mg} / \mathrm{g}$ body weight; Promega) was injected intraperitoneally. After 20min incubation, mice were anaesthetized with isoflurane and luciferase activity was measured by the IVIS Spectrum In Vivo Imaging System (PerkinElmer, Waltham, USA). Luciferase activity was measured by detecting the emitted photons per second (intensity). Lung tumor load analysis was done as previously described in [40]. In vivo blocking of PD-1, PD-L1 or the respective isotype controls IgG2a, $\operatorname{IgG} 2 b$ was done by intraperitoneal injection. $\alpha \mathrm{PD}-$ 1 (RMP1-14, Hölzel Diagnostika) and rat IgG2a 2A3 isotype control or $\alpha$ PDL1 (B7-H1, Hölzel Diagnostika) and rat $\mathrm{IgG} 2 \mathrm{~b} \kappa$ were injected at a concentration of $150 \mu \mathrm{g} /$ mouse every 4 days for maximal four injections starting at day 8 after tumor induction. At day 20 post induction of the LL/2-luc-M38 cells, total lung cells were isolated as previously described [41]. Isolated total lung cells were in vitro re-challenged with $\alpha \mathrm{PD}-1(10 \mu \mathrm{g} / \mathrm{ml})$ or IgG2a $(10 \mu \mathrm{g} / \mathrm{ml})$ or a combination of both for $24 \mathrm{~h}$ at $37^{\circ} \mathrm{C}$, $5 \% \mathrm{CO}_{2}$.

\section{Hematoxylin and eosin (H\&E) staining of tumor bearing murine lungs}

Tumor bearing lungs were removed and fixed in $10 \%$ formalin (diluted in PBS) followed by dehydration and then embedded in paraffin. $5 \mu \mathrm{m}$ lung sections cut from the paraffin block were stained with hematoxylin and eosin in order to detect the tumor infiltrated areas.

\section{May-Gründwald-Giemsa staining}

Cytospins of total cells of the bronchoalveolar lavage fluid were stained with the May-Grünwald-Giemsa solution (Carl Roth, Karlsruhe, Germany) according to the manufacturer's protocol.

\section{Flow cytometric analysis of murine cells}

Total single lung cell suspension was prepared as previously described [41]. Total lung cells were incubated with the respective mix of surface antibodies diluted in PBS and incubated for $30 \mathrm{~min}$ at $4^{\circ} \mathrm{C}$ in the dark. For intracellular staining lung cells were fixed and permeabilized using the Fixation/ Permeabilization Concentrate/Diluent in accordance to the manufacturer's protocol (eBioScience, San Diego, CA, USA). For cytokine staining total lung cells were cultured for $24 \mathrm{~h}$ in RPMI-1640 medium (Gibco) supplemented with $10 \%$ FCS, $1 \%$ L-Glut, $1 \%$ Pen/Strep, in the presence of $10 \mu \mathrm{g} / \mathrm{ml} \alpha \mathrm{CD} 3$ and $1 \mu \mathrm{g} / \mathrm{ml} \alpha \mathrm{CD} 28$ at $37^{\circ} \mathrm{C}, 5 \% \mathrm{CO}_{2}$. Lung cells were stimulated for $4 \mathrm{~h}$ with ionomycin (1 $\mu \mathrm{M}$, Sigma-Aldrich), PMA (50 ng/ml, Sigma-Aldrich) and Golgi inhibitor monensin $(2 \mu \mathrm{M}$, eBioScience). Antibodies for intracellular staining were diluted in Permeabilization Buffer (eBioScience) and incubated for $30 \mathrm{~min}$, at $4^{\circ} \mathrm{C}$ in the dark. Flow cytometric analysis was performed with a FACS Calibur and a Canto II (BD BioScience) at the Molecular Pneumology Department. Data were examined by Cell Quest 4.02 (BD BioScience), FACS Diva (BD BioScience) and Flow-Jo 10.2 (FlowJo, LLC, Oregon, USA). Following antibodies were used for flow cytometric analysis: $\alpha \mathrm{CD} 3$ (1/200, FITC, 17A2, BD BioScience), aCD4 (1/200, FITC, H129.19, BD BioScience), aCD4 (1/200, Alexa Fluor 647, RM4-5, BD BioScience), $\alpha \mathrm{CD} 8$ (1/400, APC, 53-6.7, BD BioScience), $\alpha \mathrm{CD} 8$ (1/200, PerCp, 53.6-7), $\alpha \mathrm{CD} 11 \beta(1 / 200, \mathrm{APC}, \mathrm{M} 1 / 70, \mathrm{BD}$ BioScience), $\alpha \mathrm{CD} 25$ (1/100, PerCpCy5.5, PC61, BD BioScience), $\alpha$ PD-1 (1/200, APC, J43, BD BioScience), aPD-L1 (1/200, PE, MIH5, BD BioScience), $\alpha \mathrm{F} 4 / 80$ (1/200, PerCp, BM8, BD BioScience), $\alpha$ TNFR1 (1/100, PE, HM104, ThermoFisher), $\alpha$ TNF R Type II (1/100, PE, TR75-89, BioLegend), $\alpha$ Tbet (1/20, PE, O4-46, BD BioScience), $\alpha$ Foxp3 (1/20, APC, 3G3, Miltenyi Biotec), $\alpha \mathrm{TNF} \alpha$ (1/200, APC, Mab11, BD BioScience), $\alpha$ Eomes (1/150, e-Fluor780, eBioScience).

\section{Apoptosis assay}

$10^{5}$ cells were harvested and stained with Annexin V FITC (BD, BioScience) and Propidium iodide (BD, BioScience) dissolved in $1 \times$ Annexin V Binding Buffer (BD, BioScience). After 15 min incubation in the dark at room temperature (RT), apoptosis assay was analyzed by using FACS Calibur and FACS CantoII (BD BioScience, Franklin, Lakes, USA). Data sets were analyzed by FlowJoV10 (FlowJo, LLC, Oregon, USA).

\section{Generation of bone marrow-derived macrophages (BMDM) and M1 differentiation assay}

Femur and tibia were dissected and cleaned from muscles without injuring the bone. Bones were sterilized in $70 \%$ ethanol. Bones were opened at their poles and bone marrow cells were flushed out with RPMI-1640 (Gibco) using a 20 Gauge needle. Cells were centrifuged at $300 \mathrm{~g}, 10 \mathrm{~min}$ at $4^{\circ} \mathrm{C}$ and resuspended in $5 \mathrm{ml}$ ammonium-chloride-potassium (ACK) lysis buffer in order to lyse erythrocytes. Cells were centrifuged at $1500 \mathrm{rpm}, 5 \mathrm{~min}$ and $4^{\circ} \mathrm{C}$ and washed with RPMI-1640 (Gibco) supplemented with $10 \%$ FCS. After another centrifugation step (1500 rpm, $\left.5 \mathrm{~min}, 4^{\circ} \mathrm{C}\right)$ cells were 
seeded in BMG-medium RPMI 1640 supplemented with 10\% FCS, 1\% Pen/Strep, 1\% L-Glut, 1\% NEA-Mix, 1\% Sodium pyruvate, 5\% Panexin, 2\% $\beta$-Mercaptoethanol and $0.05 \%$ recombinant $\mathrm{M}-\mathrm{CSF}$ (BioLegend, Eching, Germany) and plated on $6 \mathrm{~cm}$ petri dishes. On day 4 and 8 medium was changed to remove floating cells. For macrophage differentiation assay, samples were detached on day 11 and stimulated with Lipopolysaccharide (LPS, $0.1 \mu \mathrm{g} / \mathrm{ml}$, Sigma-Aldrich) and IFNg $(0.01 \mu \mathrm{g} / \mathrm{ml}$, BioLegend) for $48 \mathrm{~h}$ at $37^{\circ} \mathrm{C}, 5 \% \mathrm{CO}_{2}$ and then harvested for qPCR analysis.

\section{Isolation of murine $\mathrm{CD8}^{+}$and $\mathrm{CD} 11 \mathrm{~b}^{+}$cells from naïve or tumor bearing lungs}

Single cell suspension from tumor bearing or naïve murine lungs were prepared as previously described in [41]. $\mathrm{CD}^{+}$cells were isolated from tumor bearing or naïve lungs by magnetic cell separation using CD8a (Ly-2) MircoBeads, mouse kit (Miltenyi Biotec) in accordance to the manufacturer's instructions. $\mathrm{CD}_{11 \mathrm{~b}^{+}}$cells were isolated from lungs from tumor bearing mice using the CD11b MicroBeads, human and mouse kit (Miltenyi Biotec) according to the manufacturer's instructions. Isolated cells were cultured in RMPI-1640 supplemented with $10 \%$ FCS, $1 \%$ L-Glut and $1 \%$ Pen/Strep in the presence of $\alpha \mathrm{CD} 3(10 \mu \mathrm{g} / \mathrm{ml}, \mathrm{BD}$ BioScience $)$ and $\alpha \mathrm{CD} 28$ ( $1 \mu \mathrm{g} / \mathrm{ml}$, BioLegend). After $24 \mathrm{~h}$ incubation at $37^{\circ} \mathrm{C}$, $5 \% \mathrm{CO}_{2}$ supernatants were collected and used for Cell Viability Assay.

\section{Statistical analysis}

Statistics were performed with Graph-Pad Prism7. The unpaired $t$-test was used for parametric data containing no more than two groups. Linear regression analysis was used for correlation analysis. Data are presented as mean \pm SEM and significance levels indicated as follows: ${ }^{*} p \leq 0.05,{ }^{* *} p \leq 0.01,{ }^{* * *} p \leq 0.001$.

\section{Author contributions}

SF supervised this study and revised the manuscript. JF and SF designed the project and JF wrote the manuscript. JF planned and performed the experiments and analyzed the data sets. JF created the figures. LH contributed to the patient samples collection. DIT and HS did the surgery and provided and indexing the human lung biopsies. MC provided the STAT1 KO mice. RJR did the pathological characterization and digitalization of the human tissue arrays originated from those biopsies.

\section{ACKNOWLEDGMENTS}

We thank the whole team, especially Adriana Geiger, Susanne Mittler and Sonja Trump for their technical help in the animal facility, collecting human samples and technical help in the laboratory at the Department of Molecular Pneumology, the Institute of Pathology at the Friedrich-Alexander University Erlangen-Nürnberg and the Department of Thoracic Surgery at the FriedrichAlexander-University Erlangen-Nürnberg for their support and technical help. This work was financially supported by the Department of Molecular Pneumology, a grant from the IZKF (Interdisciplinary Center for Clinical Research) and a DFG grant (Deutsche Forschungsgesellschaft FI8176-1), both awarded to Prof. Dr. Dr. Susetta Finotto.

\section{CONFLICTS OF INTEREST}

The authors declare no conflicts of interest on the matter described in this manuscript.

\section{FUNDING}

Juliane Friedrich $\mathrm{PhD}$ position and this study were supported by an IZKF grant A59 and from a grant from the DFG-FI-817/6-1 awarded to Prof. Susetta Finotto at the Department of Molecular Pneumology in Erlangen.

\section{REFERENCES}

1. Pardoll DM, Drew M. The blockade of immune checkpoints in cancer immunotherapy. Nat Rev Cancer. 2012; 12:252.

2. Taube JM, Anders RA, Young GD, Xu H, Sharma R, McMiller TL, Chen S, Klein AP, Pardoll DM, Topalian SL, Chen L. Colocalization of inflammatory response with B7-h1 expression in human melanocytic lesions supports an adaptive resistance mechanism of immune escape. Sci Transl Med. 2012; 4:127ra137-127ra137.

3. Mandai M, Hamanishi J, Abiko K, Matsumura N, Baba $\mathrm{T}$, Konishi I. Dual faces of IFN $\gamma$ in cancer progression: a role of PD-L1 induction in the determination of pro-and antitumor immunity. Clinical Cancer Research. 2016; 22:2329-2334.

4. Wallace FA, Neely SJ, Miles EA, Calder PC. Dietary fats affect macrophage-mediated cytotoxicity towards tumour cells. Immunol Cell Biol. 2000; 78:40-48.

5. Wang X, Lin Y. Tumor necrosis factor and cancer, buddies or foes? Acta Pharmacologica Sinica. 2008; 29:1275-1288.

6. Chen PL, Roh W, Reuben A, Cooper ZA, Spencer CN, Prieto PA, Miller JP, Bassett RL, Gopalakrishnan V, Wani K, De Macedo MP, Austin Breneman JL, Jiang H, et al. Analysis of immune signatures in longitudinal tumor samples yields insight into biomarkers of response and 
mechanisms of resistance to immune checkpoint blockade. Cancer Discov. 2016; 6:827-837.

7. Herbst RS, Soria JC, Kowanetz M, Fine GD, Hamid O, Gordon MS, Sosman JA, McDermott DF, Powderly JD, Gettinger SN, Kohrt HE, Horn L, Lawrence DP, et al. Predictive correlates of response to the anti-PD-L1 antibody MPDL3280A in cancer patients. Nature. 2014; 515:563.

8. Larkin J, Chiarion-Sileni V, Gonzalez R, Grob JJ, Cowey CL, Lao CD, Schadendorf D, Dummer R, Smylie M, Rutkowski P, Ferrucci PF, Hill A, Wagstaff J, et al. Combined nivolumab and ipilimumab or monotherapy in untreated melanoma. N Engl J Med. 2015; 373:23-34.

9. Powles T, Eder JP, Fine GD, Braiteh FS, Loriot Y, Cruz C, Bellmunt J, Burris HA, Petrylak DP, Teng SL, Shen X, Boyd Z, Hegde PS, et al. MPDL3280A (anti-PD-L1) treatment leads to clinical activity in metastatic bladder cancer. Nature. 2014; 515:558.

10. Postow MA, Callahan MK, Wolchok JD. Immune checkpoint blockade in cancer therapy. J Clin Oncol. 2015; 33:1974.

11. Robert C, Long GV, Brady B, Dutriaux C, Maio M, Mortier L, Hassel JC, Rutkowski P, McNeil C, Kalinka-Warzocha E, Savage KJ, Hernberg MM, Lebbé C, et al. Nivolumab in previously untreated melanoma without BRAF mutation. N Engl J Med. 2015; 372:320-330.

12. Robert C, Schachter J, Long GV, Arance A, Grob JJ, Mortier L, Daud A, Carlino MS, McNeil C, Lotem M, Larkin J, Lorigan P, Neyns B, et al. Pembrolizumab versus ipilimumab in advanced melanoma. N Engl J Med. 2015; 372:2521-2532.

13. Taube JM, Klein AP, Brahmer JR, Xu H, Pan X, Kim JH, Chen L, Pardoll DM, Topalian SL, Anders RA. Association of PD-1, PD-1 ligands, and other features of the tumor immune microenvironment with response to anti-PD-1 therapy. Clin Cancer Res. 2014; 20:5064-74.

14. Garon EB, Rizvi NA, Hui R, Leighl N, Balmanoukian AS, Eder JP, Patnaik A, Aggarwal C, Gubens M, Horn L, Carcereny E, Ahn MJ, Felip E, et al. Pembrolizumab for the treatment of non-small-cell lung cancer. N Engl J Med. 2015; 372:2018-2028.

15. Lau J, Cheung J, Navarro A, Lianoglou S, Haley B, Totpal K, Sanders L, Koeppen H, Caplazi P, McBride J, Chiu H, Hong R, Grogan J, et al. Tumour and host cell PD-L1 is required to mediate suppression of anti-tumour immunity in mice. Nature Communications. 2017; 8:14572.

16. Andreev K, Trufa DI, Siegemund R, Rieker R, Hartmann A, Schmidt J, Sirbu H, Finotto S. Impaired T-bet-pSTAT1a and perforin-mediated immune responses in the tumoral region of lung adenocarcinoma. Br J Cancer. 2016; 115:e11.

17. Pensa S, Regis G, Boselli D, Novelli F, Poli V. STAT1 and STAT3 in tumorigenesis: two sides of the same coin? 2013. In: Madame Curie Bioscience Database [Internet]. Austin (TX): Landes Bioscience; 2000-2013. Available from: https://www.ncbi.nlm.nih.gov/books/NBK6568/.
18. Lu C, Talukder A, Savage NM, Singh N, Liu K. JAK-STAT-mediated chronic inflammation impairs cytotoxic $T$ lymphocyte activation to decrease anti-PD-1 immunotherapy efficacy in pancreatic cancer. Oncoimmunology. 2017; 6:e1291106.

19. Heim L, Friedrich J, Engelhardt M, Trufa DI, Geppert CI, Rieker RJ, Sirbu H, Finotto S. NFATc1 promotes anti-tumoral effector functions and memory CD8+ T cell differentiation during non-small cell lung cancer development. Cancer Res. 2018; 78:3619-3633.

20. Chapgier A, Kong XF, Boisson-Dupuis S, Jouanguy E, Averbuch D, Feinberg J, Zhang SY, Bustamante J, Vogt G, Lejeune J, Mayola E, de Beaucoudrey L, Abel L, et al. A partial form of recessive STAT1 deficiency in humans. J Clin Invest. 2009; 119:1502-1514.

21. Andreev K, Trufa DI, Siegemund R, Rieker R, Hartmann A, Schmidt J, Sirbu H, Finotto S. Impaired T-bet-pSTAT1 $\alpha$ and perforin-mediated immune responses in the tumoral region of lung adenocarcinoma. Br J Cancer. 2015; 113:902.

22. Iwai Y, Ishida M, Tanaka Y, Okazaki T, Honjo T, Minato $\mathrm{N}$. Involvement of PD-L1 on tumor cells in the escape from host immune system and tumor immunotherapy by PD-L1 blockade. Proc Natl Acad Sci U S A. 2002; 99:12293-12297.

23. Cho HJ, Jung JI, Kwon GT, Her S, Park JH, Park JH. Bone marrow-derived, alternatively activated macrophages enhance solid tumor growth and lung metastasis of mammary carcinoma cells in a Balb/C mouse orthotopic model. Breast Cancer Res. 2012; 14:R81.

24. Kamijo R, Harada H, Matsuyama T, Bosland M, Gerecitano J, Shapiro D, Le J, Koh S, Kimura T, Green S, Mak T, Taniguchi T, Vilček J, et al. Requirement for transcription factor IRF-1 in NO synthase induction in macrophages. Science. 1994; 263:1612-1615.

25. Olazabal IM, Martín-Cofreces NB, Mittelbrunn M, del Hoyo GM, Alarcón B, Sánchez-Madrid F. Activation outcomes induced in naive CD8 T-cells by macrophages primed via "phagocytic" and nonphagocytic pathways. Mol Biol Cell. 2008; 19:701-710.

26. Chen L, Flies DB. Molecular mechanisms of $\mathrm{T}$ cell co-stimulation and co-inhibition. Nat Rev Immunol. 2013; 13:227.

27. Sharma P, Hu-Lieskovan S, Wargo JA, Ribas A. Primary, adaptive, and acquired resistance to cancer immunotherapy. Cell. 2017; 168:707-723.

28. Ganesan AP, Clarke J, Wood O, Garrido-Martin EM, Chee SJ, Mellows T, Samaniego-Castruita D, Singh D, Seumois G, Alzetani A, Woo E, Friedmann PS, King EV, et al. Tissue-resident memory features are linked to the magnitude of cytotoxic $\mathrm{T}$ cell responses in human lung cancer. Nat Immunol. 2017; 18:940.

29. Li Q, Li Z, Gong F, Feng W, Jiang X, Xiong P. Antitumor effects of the fibroblasts transfected TNF- $\alpha$ gene and its 
mutants. J Huazhong Univ Sci Technolog Med Sci. 2002; 22:92-95.

30. Kriegler M, Perez C, DeFay K, Albert I, Lu S. A novel form of TNF/cachectin is a cell surface cytotoxic transmembrane protein: ramifications for the complex physiology of TNF. Cell. 1988; 53:45-53.

31. Ardestani S, Li B, Deskins D, Wu H, Massion P, Young P. Membrane versus Soluble Isoforms of TNF-alpha Exert Opposing Effects on Tumor Growth and Survival of TumorAssociated Myeloid Cells (vol 73, pg 3938, 2013). Cancer Res. 2014; 74:976-976.

32. Grell M, Douni E, Wajant H, Löhden M, Clauss M, Maxeiner B, Georgopoulos S, Lesslauer W, Kollias G, Pfizenmaier K, Scheurich P. The transmembrane form of tumor necrosis factor is the prime activating ligand of the 80 kDa tumor necrosis factor receptor. Cell. 1995; 83:793-802.

33. Wenfang S, Zhuoya L, Feili G. Comparison of the cytocidal effect induced by transmembrane and secreted TNF alpha. Chinese Journal of Microbiology and Immunology. 1998; 18:499-504.

34. Jiang Y, Yu M, Hu X, Han L, Yang K, Ba H, Zhang Z, Yin B, Yang XP, Li Z, Wang J. STAT1 mediates transmembrane TNF-alpha-induced formation of death-inducing signaling complex and apoptotic signaling via TNFR1. Cell Death Differ. 2017; 24:660-671.

35. Bertrand F, Montfort A, Marcheteau E, Imbert C, Gilhodes J, Filleron T, Rochaix P, Andrieu-Abadie N, Levade T, Meyer N, Colacios C, Ségui B. TNF $\alpha$ blockade overcomes resistance to anti-PD-1 in experimental melanoma. Nat Commun. 2017; 8:2256.
36. Zakharova N, Lymar ES, Yang E, Malik S, Zhang JJ, Roeder RG, Darnell JE. Distinct transcriptional activation functions of STAT $1 \alpha$ and STAT1 $\beta$ on DNA and chromatin templates. J Biol Chem. 2003; 278:43067-43073.

37. Goodman RH, Smolik S. CBP/p300 in cell growth, transformation, and development. Genes Dev. 2000; 14:1553-1577.

38. Semper C, Leitner NR, Lassnig C, Parrini M, Mahlakõiv T, Rammerstorfer M, Lorenz K, Rigler D, Müller S, Kolbe T, Vogl C, Rülicke T, Staeheli P, et al. STAT1 $\beta$ is not dominant negative and is capable of contributing to gamma interferon-dependent innate immunity. Mol Cell Biol. 2014; 34:2235-2248.

39. Eisenhut F, Heim L, Trump S, Mittler S, Sopel N, Andreev K, Ferrazzi F, Ekici AB, Rieker R, Springel R, Assmann VL, Lechmann M, Koch S, et al. FAM13A is associated with non-small cell lung cancer (NSCLC) progression and controls tumor cell proliferation and survival. Oncoimmunology. 2017; 6:e1256526.

40. Reppert S, Boross I, Koslowski M, Türeci Ö, Koch S, Lehr $\mathrm{H}$, Finotto S. A role for T-bet-mediated tumour immune surveillance in anti-IL-17A treatment of lung cancer. Nat Commun. 2011; 2:600.

41. Sauer KA, Scholtes P, Karwot R, Finotto S. Isolation of CD4+ T cells from murine lungs: a method to analyze ongoing immune responses in the lung. Nat Protoc. 2006; $1: 2870$. 